\title{
AN ASSEMBLY PERSPECTIVE OF ENTREPRENEURIAL PROJECTS: SOCIAL NETWORKS IN ACTION
}

\author{
David Obstfeld \\ Mihaylo College of Business and Economics \\ California State University, Fullerton \\ Fullerton, CA \\ Ph: 949-874-9003 \\ dobstfeld@,fullerton.edu
}

\author{
Marc J. Ventresca \\ Saïd Business School \\ University of Oxford \\ Oxford UK \\ marc.ventresca@s,sbs.ox.ac.uk
}

\author{
Greg Fisher \\ Kelley School of Business \\ Indiana University \\ Bloomington, IN \\ fisherg@indiana.edu
}

Keywords: tertius iungens; social networks; entrepreneurial projects; entrepreneurial processes; entrepreneurship theory

Acknowledgements: We would like to thank Howard Aldrich, Phil Anderson, Ted Baker, Diane Burton, Guillermo Casanovas, Tanja Collavo, Frank Day, Nicolas Dew, Ryan Farrell, Yan Gong, Matthew Grimes, Philip Guest, Tim Hannigan, Heli Helanummi-Cole, Joann Horai, Rodney Lacey, Dean Shepherd, Renee Rottner, and Alex Toll for their guidance and helpful comments. We also wish to thank Sharon Alvarez and three reviewers for their excellent guidance. 


\title{
AN ASSEMBLY PERSPECTIVE OF ENTREPRENEURIAL PROJECTS: SOCIAL NETWORKS IN ACTION
}

\begin{abstract}
We introduce a process model of microsocial network dynamics that incorporates an assembly perspective of entrepreneurial action in early-stage projects. The model comprises four conceptual elements: (1) an initial entrepreneurial projection or goal, which motivates and guides network-based action, and evolves as it is the venture unfolds; (2) knowledge articulation to make the entrepreneurial projection relevant to stakeholders; (3) combinatorial action, which entails joining people and resources in new combinations and that may reshape the project; and (4) network expansion by which stakeholder relationships develop and generate distributed momentum. This approach integrates and extends foundational theoretical perspectives in entrepreneurship — bricolage, effectuation, and opportunity creation, drawing on recent developments in social network process theory to inform the model.
\end{abstract}


Entrepreneurs rely on connections to get things done. Research perspectives on the actions and behaviors underpinning early-stage entrepreneurial projects recognize the relevance of networks and social interaction to such projects. Approaches such as effectuation (Sarasvathy, 2001), bricolage (Baker and Nelson, 2005), and opportunity creation theory (Alvarez and Barney, 2007) identify an entrepreneur's connections to and interactions with other individuals and entities as a key input and enabler of the entrepreneurship process. For example, Alvarez and Barney (2007: 19) suggest that opportunity creation entails "recruiting flexible general human capital from pre-existing social networks.” Sarasvathy (2001: 2001) describes effectuation in entrepreneurship as a process in which entrepreneurs leverage "whom they know... the social networks they are a part of." Baker and colleagues (2003: 250) describe how entrepreneurs engage in bricolage by relying on "pre-existing networks as their primary means of access to the welter of resources needed during and after (venture) founding."

These foundational perspectives underscore the importance of social networks to the entrepreneurial process, but they depict network ties primarily as an existing resource and treat social networks and their operational contexts as relatively stable over the life of a venture. None of these perspectives explicitly account for the assembly of such networks or how networks evolve as an entrepreneurial project unfolds. Yet, individuals who initiate entrepreneurial projects regularly cultivate their networks and, in so doing, change the project context, engaging with others to forge new collaborations (Fang, Chi, Chen and Baron, 2015). This 'connecting' activity is an important omission in the research literature. Recent empirical and theoretical work on social networks highlights the dynamic, ongoing cultivation by which entrepreneurial actors grow and leverage venture networks (Obstfeld, 2012; Obstfeld, Borgatti, and Davis, 2014; Long Lingo and O’Mahony 2010). Social networks are seldom stable, and in 
the dynamic context of entrepreneurship, they emerge and evolve with a great deal of fluidity (Fang et al., 2015; Vissa, 2012). Entrepreneurs depend heavily on their social networks for information (Ozgen and Baron, 2007; Sarasvathy, 2001), resources (Alvarez and Barney, 2007; Baker and Nelson, 2005; Eisenhardt and Schoonhoven, 1996; Uzzi, 1999), and access to markets (Robinson, 2006). These empirical studies provide a rich set of new insights and merit analytic attention. We build from these studies, to propose a model that integrates this work on the assembly and evolution of entrepreneurial networks.

This conceptual model, and its accompanying arguments specifically account for the creation and evolution of network ties and social connections in the pursuit of an entrepreneurial project over time. In doing this, we present the assembly-based perspective of entrepreneurial action. The term "assembly" foregrounds key ideas in recent research on social action in entrepreneurship that stress the active construction of opportunities over time as treated in effectuation, bricolage, and opportunity creation. This more dynamic grasp of entrepreneurial process dovetails with recent developments in the social network literature that account for evolutionary and process-oriented studies of social networks (e.g., Obstfeld, 2012; Obstfeld, Borgatti, and Davis, 2014; Long Lingo and O’Mahony 2010; Vissa, 2011). We incorporate this work to develop an account of how early-stage entrepreneurial opportunities are assembled through networks and network process. The assembly model emphasizes the idea of an emergent "project" motivated by an entrepreneurial projection or goal and the key activities of articulating that projection to different stakeholders along existing and newly created ties, and then selectively connecting stakeholders in an array of combinations of actors that unfold over time. We delineate four animating mechanisms that support a model of entrepreneurial action, including entrepreneurial projection, knowledge articulation, 
combinatorial action, and network expansion. We map these dynamics at the level of the entrepreneurial project.

\section{FOUNDATIONAL APPROACHES TO ENTREPRENEURSHIP}

Contemporary foundational approaches to entrepreneurship, including effectuation (Sarasvathy, 2001, 2008), bricolage (Baker and Nelson, 2005; Garud and Karnoe, 2003), and creation theory (Alvarez and Barney, 2007; Alvarez et al. 2013; Welter et al., 2016) acknowledge that entrepreneurial action occurs within the context of social networks; yet, none of these approaches explicitly account for the actions to establish and evolve such networks as an entrepreneurial project unfolds. In this section, we review how these contemporary entrepreneurship perspectives treat social networks. Table 1 provides a summary overview.

\section{Effectuation}

Effectuation theory shifts attention from the goals of entrepreneurial action to the available means as a basis for action (Sarasvathy, 2001, 2008). Sarasvathy (2008) specifies three categories of means relevant to an entrepreneur: "who I am," "what I know," and "who I know." Effectuation theory implies that expert entrepreneurs forge opportunities and take action based on those three categories of means. The "who I know" category accounts for the importance of an entrepreneur's social network as a basis for entrepreneurial action; they do this by considering how they can use the relationships and the other means at their disposal to create value. Sarasvathy (2008: 73) characterizes entrepreneurial action as "non-teleological— i.e., not taking preferences and goals as pre-existent or unchangeable..." and, instead, emphasizes the "bird-in-hand" principle of "starting with the means and creating new effects" (Sarasvathy, 2008: 73-74). Emphasizing these characteristics, Sarasvathy (2008: 73; 2001) critiques rational-action theories involving "causal reasoning" (i.e., "beginning with a specific 
goal and a given set of means for reaching it") and prediction (assuming probabilities are “given or immutable").

Effectuation theory also underscores the importance of intermediate moves that create "affordable losses" and allow provisional control. The logic of effectuation reinforces the critique of goal-oriented entrepreneurship by lean startup advocates and practitioners (Blank, 2013; Reis, 2011). They, pointedly reject business plans as based on a wrong-headed investment in a priori product definition, target market, and financial-performance predictions. The movement favors, instead, a more emergent conception of entrepreneurship that allows for adjustments or pivots based on ongoing engagement with customers and other stakeholders. The recent effectuation literature references networks in use. For example, Engel, Kaandorp, and Elfring (2017: 41) emphasize the relative absence or "at best ambiguous" nature of the entrepreneur's goals as a point of departure and present the entrepreneur as engaging both new and existing ties to assess the available resources and develop their goals.

The assembly approach pushes this insight one step further: We advance a social network process perspective that asserts the central role of an a priori yet provisional and evolving entrepreneurial projection — a vision of a future end state that motivates and guides network-based action built around ongoing sequences of communication and combinatorial action. In addition, our examination of these dynamics underscores the entrepreneur's engagement of existing and new ties but also explores the larger networks that entrepreneurs construct and mobilize around their ventures over time.

\section{Bricolage}

Bricolage provides a resource-focused view of entrepreneurship in the context of scarcity (Baker and Nelson, 2005; Garud and Karnoe, 2003). Baker and Nelson define bricolage as "making do by applying combinations of the resources at hand to new problems 
and opportunities" (Baker and Nelson 2005: 333). The bricolage perspective reinforces the importance of resource combination for entrepreneurial activity. Levi-Strauss first introduced the term "bricolage" by contrasting the work of the "bricoleur" with that of the "engineer," noting 'the 'bricoleur' is adept at performing a large number of diverse tasks but, unlike the engineer, does not subordinate each of them to the availability of raw materials and tools conceived and procured for the purpose of the project" (1966: 17). In other words, the bricoleur makes do with combinations of whatever resources are at hand as he or she engages the world.

In an entrepreneurial context, the bricoleur begins by relying on available tools "on the principle that 'they may always come in handy"' (Baker and Nelson, 2005: 336). By offering an alternative to external resource-seeking behavior commonly associated with some conceptions of entrepreneurship (e.g., Brush, Greene and Hart, 2001; Jarillo, 1989), bricolage forces disciplined scrutiny of an alternative path of entrepreneurial action. Scholars have extended this emphasis on the tools-or-resources-at-hand condition to an assumption that bricolage occurs within pre-existing networks (Baker, Miner, and Eesley, 2003). The relevance of networks was recognized early in the development of this perspective. We argue that the resource combination illuminated by bricolage necessarily proceeds on, and is sometimes defined through network processes whereby entrepreneurs connect actors along with the resources they bear.

\section{Creation theory}

The entrepreneurship literature currently reflects an important dialogue on the nature of entrepreneurial opportunities. A central part of this debate concerns whether entrepreneurial opportunities have an independent, objective existence that needs only be "discovered" by the entrepreneur, or, alternatively, whether the entrepreneur "creates" opportunity by engaging in action. Several scholars have developed the "creation" view of opportunities, presenting 
opportunities as necessarily socially created via enactment, effectuation, bricolage, improvisation, and experimentation (Alvarez and Barney, 2007; Venkataraman, Sarasvathy, Dew, and Forster, 2012; Alvarez, Young, and Woolley, 2015, Welter et al., 2016). One emphasis of the creation perspective is how the entrepreneur enacts opportunities in the face of uncertainty, when the possible outcomes and their likelihood are unknown (Alvarez, Barney, and Anderson, 2013). In describing how the entrepreneur engages action, creation theory particularly emphasizes Weick's conceptualization of enactment and evolutionary theories of action (Alvarez and Barney, 2007). That evolutionary perspective, according to Weick, Sutcliffe, and Obstfeld, (2005: 414), proposes that sensemaking can be treated as reciprocal exchanges between actors (Enactment) and their environments (Ecological Change) that are made meaningful (Selection) and preserved (Retention). Key to sensemaking in this view is actors' "noticing and bracketing, [of] discrepancies and equivocality in ongoing projects [that] begin to change the flux of circumstances into the orderliness of situations." This suggests, by extension, that entrepreneurs notice and respond to anomalies in their environment and continually engage their social networks to shape and pursue entrepreneurial opportunities. We argue that this initial noticing and bracketing of environmental variations is a critical part of the formation of an entrepreneurial projection that motivates and guides network assembly and, having identified a provisional goal, entrepreneurs engage and orchestrate the networks that surround them as a means of creating opportunities.

\section{Effectuation, bricolage, creation theory, and social networks}

The comparison of bricolage, effectuation, and creation theory suggests a common emphasis on how the entrepreneur creates and pursues opportunities in a social context. See Table 2 for an overview summary. These perspectives assert that entrepreneurs have agency and embrace action; the entrepreneur must act for an opportunity to be realized. These 
approaches also acknowledge a process through which opportunities are socially constructed and resources are acquired to act on those opportunities. Bricolage, effectuation, and opportunity creation reflect a shift to a pragmatic view of action whereby an entrepreneur's understanding of the available resources and abilities shapes action in a social context as much as a priori goals or predictive calculation do (Fisher, 2012; Welter et al., 2016).

These theories provide inherently social accounts of action, including foundations and purposes of action. And given that, it is not surprising that all three approaches invoke the entrepreneur's social network ties as important resources to prompt and promote action in the entrepreneurial process. They each provide distinctive accounts. The effectuation perspective conceptualizes social ties as a launching point for engaging in entrepreneurial action, an original location in social space (Sarasvathy, 2001, 2008). The bricolage perspective conceptualizes an entrepreneur's network ties in multiple, crosscutting social contexts as the means to access scarce resources, thereby overcoming resource constraints (Baker and Nelson, 2005). The creation perspective posits that entrepreneurs enact their ideas by recruiting general human capital from pre-existing social networks (Alvarez and Barney, 2007: 19). While each perspective recognizes the embeddedness of entrepreneurs and the importance of social networks as a means to access resources, they underspecify how the early, active assembly of networks occurs at the project level and how that evolves over the life of the project.

These approaches capture an important social dimension and acknowledge the role of networks. They remain "structural" accounts in their treatment of networks as fixed circumstances that either enable or constrain entrepreneurial action. These foundational theories of entrepreneurial action neglect to specify how the network surrounding an entrepreneurial project comes to be and how it evolves during the entrepreneurial journey. This omission is understandable given the other insights that each perspective offers; to address the 
gap, we use networks and network theory as conceptual tools to extend the common recognition of early startups' emergent social context.

Using this critique as a point of departure, we first reflect on recent entrepreneurship literature that describes entrepreneurship as a highly social process in which a group (rather than an individual) operates to bring new things into being. Second, we elaborate on recent advancements in the social networks literature that account for the dynamic and evolving nature of social networks. This lays the foundation to more fully specify how the dynamics of entrepreneurial networks inform entrepreneurial action and assembly. In so doing, we offer an account that bridges the three foundational approaches, to explain how entrepreneurs leverage and transform their contexts through dynamic social network processes.

\section{Entrepreneurship as a broader social process}

Beyond the three perspectives we emphasize above, a rich body of descriptive and normative work has started to conceptualize entrepreneurship as embedded in social interactions between entrepreneurs and their stakeholders (Stinchcombe, 1965; Van de Ven and Polley, 1992; Smith and Gregorio, 2002; McMullen and Shepherd, 2006). This work suggests that social interactions among entrepreneurs and other actors may significantly shape and reshape the entrepreneurial process (e.g., Gartner, Bird, and Starr, 1992).

Ruef (2010), for example, critiques the individual-focused perspectives of both popular and academic entrepreneurship authors. He argues that the emphasis on heroic individuals omits the structural context and collective action of economic actors. As a corrective, Ruef

(2010) foregrounds a focus on collective action in the entrepreneurial process:

Startup efforts...involve collective action that is oriented toward the founding of a new organization. Entrepreneurs, in this conception, are defined by their intention to form a social group. (our emphasis) An emphasis on entrepreneurial groups does not lead to an elision of the question as to "who is an entrepreneur?" but reconceptualizes it in fundamental respects. The porous boundaries of 
entrepreneurial groups argue against simple answers to [such] questions and, instead, call attention to the social and economic processes that embed individuals in entrepreneurial activity.

Ruef (2010: 15) describes the entrepreneurial group as "the set of actors - either individual or organizational—who actively support the creation of a new organization." This collectiveaction perspective emphasizes microsocial combinatorial actions that give rise to such groups. ${ }^{1}$

This work echoes and extends Gartner's (1989) pioneering focus on the process of organizational emergence, which involves multiple actors (Gartner et al., 1992) rather than accounting for discrete outcomes such as the founding of a firm or venture success. Ruef marshals data suggesting that most "entrepreneurial partnerships are generally formed as open groups" (2010: 10). Hence, microsocial combinatorial processes, in which actors purposefully combine people and the skills, resources, and effort they bear, to work together in groups, are central to entrepreneurial projects. In this paper, we further unpack the microsocial combinatorial process identified by Ruef, to suggest that such action occurs not necessarily in one locale, but is distributed over time and place in a trajectory. We portray the entrepreneur as an actor who not only sees and acts on opportunity, but who has a distinctive ability to assemble distributed resources, beginning with interactions and relationships.

\section{The dynamism of social networks within entrepreneurship}

Recent advancements in the social network literature account for the dynamic, evolutionary, and process-oriented nature of social networks (e.g., Obstfeld, 2012; Obstfeld, Borgatti, and Davis, 2014; Long Lingo and O'Mahony 2010). Social theorists as far back as

\footnotetext{
${ }^{1}$ Related literature on entrepreneurial teams (Cooney, 2005; Harper, 2008, Schjoedt et al., 2013) recognizes the importance of the early actors who come together to drive an entrepreneurial startup. Harper (2008: 617), for example, critiques the individualistic orientation at the root of leading theories of entrepreneurship and argues for the importance of the entrepreneurial team defined as a "group of entrepreneurs with a common goal that can only be achieved by appropriate combinations of individual entrepreneurial actions."
} 
White (1992) investigated how network research might illuminate how agents "get action" (e.g., Emirbayer and Mische, 1998). This research thread connecting outcomes to social networks characterized networks as having a somewhat fixed structure; they serve as a stable resource that might constrain or enable entrepreneurial outcomes (Ruef, Aldrich, and Carter, 2003). This more recent research advances an earlier networks and entrepreneurship literature that studied networks in terms of fixed attributes such as tie content (e.g., strong and weak ties), network structure, and governance (e.g., Davidsson and Honig, 2003; Hoang and Antoncic, 2003; Watson 2007) to provide important step change for insight into entrepreneurial processes.

Recent studies have examined a dynamic, action-oriented theory of entrepreneurship that shifts emphasis from networks shaping entrepreneurs to entrepreneurs shaping their networks. A key theme in this research is the entrepreneur's strategic formation of relational ties (Hallen and Eisenhardt, 2012; Stuart and Sorenson, 2007). One thread, for example, explores issues associated with new tie formation (Elfring and Hulsnink, 2007; Vissa and Chacar, 2009; Vissa, 2011), including the tension between creating new ties versus managing existing contacts (Vissa, 2012; Mariotti and Delbridge, 2012) and the means by which entrepreneurs secure tie-formation efficiency in the face of scarce entrepreneurial resources (Hallen and Eisenhardt, 2012). Other research examines a process view of how entrepreneurs secure alliance partners by visualizing their positioning and opportunities for coordination within the larger network (Ozcan and Eisenhardt, 2009). For the most part, this work emphasizes dyadic ties but neglects to address the mobilization of those ties and the construction of constellations of network-based support.

Also working in this action-oriented vein but identifying mechanisms more complex than dyadic tie formation, Long Lingo and O'Mahony (2010) found that the interplay of 
different coordinative brokerage strategies within networks was critical to the execution of Nashville country music producers' creative projects. They argue that a focus on the "dynamic practice of brokerage" corrects the excessively structural view of brokers, puts the idea "in action," and acknowledges the wider collective that makes the creative outcomes possible: "Brokers cannot achieve benefits from their unique position on their own; they are pursuing collective goals that require the creative talents of others" (Long Lingo and O'Mahony 2010: 49).

We build from these recent contributions and link them more directly to early moments of entrepreneurial ventures and the projects that animate them. We address the combinatorial processes by which entrepreneurs connect initial constellations of support and collaboration and assemble networks for entrepreneurial creation (Stuart and Sorenson, 2007). In examining such dynamics, we do not refer to the founding of a firm as a defining entrepreneurial event because we wish to focus on entrepreneurial action prior to a formal founding. We also deemphasize metrics of entrepreneurial "success" and instead home in on social action and interactions as a key input into entrepreneurial projects. This focus aligns with the argument of Alvarez, Barney, and Anderson (2013: 303):

Such [wealth-based] definitions make it difficult to evaluate entrepreneurial behavior because they suggest that entrepreneurs are only entrepreneurs if they generate economic wealth. The approach adopted here is that entrepreneurs seek to generate such wealth. Their ability to do so depends on their skills as entrepreneurs, their good fortune, and so forth. In short, this ... allows for the possibility of numerous failed entrepreneurs - those who have sought to exploit opportunities but have been unable to do so-in the economy.

Alvarez and colleagues (2013) shift attention to entrepreneurial action, an emphasis we develop to understand network assembly at the level of a project. We define entrepreneurial action as the microsocial action necessary to transform ideas into action that has impact. Here, "microsocial" means social processes involving relatively small numbers of actors (i.e., from 
two to two dozen) who initiate, in the language of early sociologists of action, a "going concern" (Hughes, 1971; Becker, 1986; Hallett and Ventresca, 2006; Ventresca and Kaghan 2008).

\section{AN ASSEMBLY PERSPECTIVE OF ENTREPRENEURIAL ACTION}

An assembly perspective proposes that actors work within their existing, still-to-be created, and distributed network ties to initiate and orchestrate new action pathways in order to engage, mobilize, and direct available resources toward an evolving purpose. We define "assembly" as network-based action to recruit, connect, and mobilize people and resources in order to move toward an evolving entrepreneurial goal. This perspective develops and integrates the previously discussed action-oriented foundational approaches in entrepreneurship with new developments in social network theory that emphasize process alongside structure (Obstfeld, 2017; Obstfeld, Borgatti and Davis, 2014; Ruef, 2010). We propose assembly-based entrepreneurial action as the means by which entrepreneurs and groups "gets new things done" (Schumpeter, 1947: 151) and, by implication, get new things started - that is, the early-stage startup work we refer to as an entrepreneurial project.

The unit of analysis for this perspective is an entrepreneurial project. We begin with the idea of the creative project, an emergent trajectory of interdependent action initiated and orchestrated by multiple actors to introduce change into a social context (Obstfeld, 2012). The entrepreneurial project stands in contrast to a well-defined and repetitive organizational routine. In employing the idea of the entrepreneurial project, we draw on Schutz's (1967) use of the project concept to examine the point at which an actor goes beyond selecting between predefined choices within easy reach, to formulate a project motivated by an "in-order-to" motive. Such future-oriented projects entail more deliberation regarding feasibility, more 
uncertainty, and more freedom — and are therefore distinct from routines, on the one hand, and mere fantasy projects, on the other.

The assembly perspective model involves four conceptual elements that underpin an entrepreneurial project: (1) an entrepreneurial projection (Obstfeld, 2012; Strauss, 1993), which motivates and guides entrepreneurial action to navigate among possible ways forward and requires interaction with others; (2) knowledge articulation, which involves discursive or representational practices to frame and contextualize projections and enlist other actors to collaborate (Obstfeld, 2012); (3) combinatorial action, which entails proactively joining people and the resources they bear in new combinations (Alvarez and Busenitz, 2001; Simmel, 1950) in pursuit of the projection; and (4) an unfolding path of network expansion, which occurs through a broadening and evolving universe of relationships and, simultaneously, increased links between people in that universe, all in pursuit of an emerging projection. Table 1 summarizes these component mechanisms.

------ Insert Table 1 about here ------

Figure 1 depicts how the four elements connect, one with another. We describe these interactions in detail below.

------ Insert Figure 1 about here ------

Our focus on network dynamics builds on emerging agreement in entrepreneurship studies on the importance of social networks and combination (Schumpeter, 1934) to entrepreneurial phenomena and, relatedly, on the social network underpinnings of combinatorial processes. Entrepreneurship scholars face the associated challenge of theorizing and charting the multiple unfolding triadic processes by which an entrepreneur serves as a broker bringing together other actors and the resources they bear (e.g., financial resources or technical expertise) over time. The importance of networks and, in particular, triadic social 
dynamics is relatively easy to appreciate conceptually but more difficult to account for, as these dynamics occur on multiple social fronts, along multiple pathways, and in forms that may lead to increased participation — and false starts—as a startup evolves.

We argue that this dynamic network activity is central to early entrepreneurial action, implicit in all three foundational theories, and therefore crucial to advance our understanding of entrepreneurial process. To do this, we elaborate the network concepts of entrepreneurial projection, knowledge articulation, combinatorial action, and network expansion as the core, interrelated elements of the assembly perspective of early-stage entrepreneurial projects. We characterize the assembly view as dynamic because the model elements interact continually with one another as an early startup unfolds and may have as much impact on an entrepreneurial outcome as do the size of the market or the inimitability of the technology.

\section{Entrepreneurial projection}

An entrepreneurial project is motivated by an entrepreneurial projection, which is an evolving vision (or goal) of an expected or desired outcome (Strauss, 1988, 1993; Obstfeld, 2012). The entrepreneurial projection is sufficiently formed so that actors can discuss it as a thing to be accomplished, but it is also susceptible to continual revision as actors gather more knowledge and form more connections. To account for the genesis of an entrepreneurial projection, we draw on both evolutionary epistemology (Weick, 1979; Alvarez and Barney, 2010) and pragmatist theory (Dewey, 2002; Joas, 1996), which recognize that the entrepreneur's enactment in some sense creates opportunities, but these theories also argue that a pre-enactment phase exists in which the entrepreneur encounters anomalies, discrepancies, or variations; if actors notice and bracket these elements, they may serve as protoypical content for the entrepreneurial projection (Weick, 1979; Weick et al., 2005). 
In noticing a problem, the entrepreneur fashions an entrepreneurial projection as a provisional "solution" and engages stakeholders in an ongoing iterative development of that solution. This action is a special case of the more general sensemaking process that involves reducing equivocality and introducing order and meaning over time.

The entrepreneurial projection likely emerges as some combination of problem, puzzle, and solution that, over time, gets refined into a provisional entrepreneurial projection. That projection, as it is consolidated, motivates and guides the entrepreneurs' actions such that they begin interacting with others to further develop the projection and bring it into existence. By "motivate," we mean that the entrepreneur's projection identifies a future state sufficiently desirable to propel him or her into action. By "guide," we mean that the entrepreneur's projection orients his or her search for relevant knowledge, resources, collaborations, and support, to drive action forward.

This matrix of motive and orientation guides subsequent choices regarding what interactions and collaborations are next and how to revise and move toward that envisioned end state. Although the entrepreneurial projection motivates and guides action, our theory of assembly assumes that the projection necessarily evolves as entrepreneurs acquire knowledge and resources and encounter constraints. Finally, the projection likely results in a picture or story concerning the trajectory for how the entrepreneur might bring that sense of the possible into being. Like the entrepreneur's projection, the trajectory itself is subject to continual updating as new knowledge, relationships, and resources emerge. In practice, the entrepreneur's account of the projection and the envisioned trajectory for pursuing it are intricately intertwined.

Entrepreneurial projects, then, begin with an entrepreneurial projection in mind, the vision of what might eventually be created, and then further comprise local action 
characterized by knowledge articulation, combinatorial action, and network expansion and action in pursuit of the emerging and evolving projection (Obstfeld, 2012; Strauss, 1993). We refer to this interplay between the network action and the developing projection as "evolving means and ends." According to this view, in the absence of an entrepreneurial projection, little interaction would happen to propel an entrepreneurial project forward; with a projection, an entrepreneur initiates action with others to move an entrepreneurial project forward.

\section{Knowledge articulation}

An entrepreneur's formation of a projection is largely internal and known only to the entrepreneur or small entrepreneurial group. Next comes the imperative process to make that projection known to a broader set of potential collaborators, investors, and myriad other stakeholders with immediate and yet-to-be-identified relevance. We call this knowledge articulation, which we define as "making knowledge explicit, useful, or relevant to the situation at hand" (Obstfeld, 2012: 1574). The articulation may include the overall nature of the entrepreneurial goal, its prospects for success, or descriptions of the unique technology involved. We use knowledge articulation (Obstfeld, 2005, 2017; Polanyi, 1958; Winter, 1987; Zollo and Winter, 2002) to refer in part to discursive as well as representational practices (e.g., stories, frames, analogies, and metaphors) (Brown and Duguid, 2001; Lounsbury and Glynn, 2001; Obstfeld et al., 2014). ${ }^{2}$ The articulation of the entrepreneurial projection is inherently social; in every exchange of knowledge, the entrepreneur must make the nature of the project relevant and useful to one or more interlocutors. These stories, frames, and analogies often function to shape and reshape a shared vision, goal, or common purpose around which an

\footnotetext{
${ }^{2}$ Using ethnography in an automotive-design environment, Obstfeld (2012) suggested three major variants of knowledge articulation, "fixing," or diagnosis and problem solving; "pitching," or presenting knowledge about an opportunity to key stakeholders for the purpose of enlisting them; and "scheming," or developing and adjusting plans to guide unfolding action, including how to enlist key stakeholders. Although all three variants interconnect, here we emphasize pitching.
} 
entrepreneur can enlist one or more actors, either provisionally or over a sustained time period (Obstfeld, 2005); in that way, the entrepreneur can begin to form a network of stakeholders with ties to one another. An entrepreneur may, for example, portray a successful new venture outcome as a means of bringing together two or more investors, employees, or collaborators. For this reason, knowledge articulation tightly intertwines with the next conceptual element in our model, combinatorial action, whereby the entrepreneur mobilizes many different constellations of actors, which may subsequently grow, wither, and/or overlap within the entrepreneurial network.

\section{Combinatorial action}

Joining is a central process within entrepreneurial-project trajectories. To get new things done in emerging organizations, one must continually join both people and resources in new combinations (Alvarez and Busenitz, 2001; Schumpeter, 1934; Simmel, 1950). New organizing is an inherently collective-action process of joining in an original way the necessary people and the resources they bear (Gartner, 1989; Reuf, 2010). This approach extends the combinatorial insight of bricolage to a broader social network context. Furthermore, this emphasis on joining conveys the interplay of multiple ties and actors rather than emphasizing only the creation or altering of ties.

The social network literature usually employs a triadic frame concept that stresses a broker's relationship to two other parties whom he or she connects but who do not have direct ties to each other (Marsden, 2002; Gould and Fernandez, 1989). Building on this tradition, Burt (1992: 18) has provided an influential view of brokerage emphasizing structural holes defined as "a separation between nonredundant contacts." In triadic social network configurations, brokers have power and influence because they serve as a connecting point between two unconnected parties. To retain such power and influence, they may purposely keep such parties 
separate, an activity referred to as tertius gaudens, a separation orientation (Burt, 1992;

Simmel, 1950). A large body of network research defines brokerage in terms of this open triad: two actors, between whom a broker stands, who do not have ties with each other.

The tertius iungens orientation (Latin for "the third who joins") identified by Obstfeld (2005: 100) reflects an alternative strategic orientation within a triadic structure, whereby a broker introduces unconnected parties and/or facilitates new coordination between parties who are already connected. This orientation underscores the micro-level combinatorial activity that occurs in the context of an entrepreneurial project and is central to the assembly perspective of entrepreneurial action. Tertius iungens involves joining people and their resources in or across organizations; it advances the social network literature's treatment of brokerage phenomena beyond its exclusive focus on social network structure, by providing a rigorous underpinning for the social mechanics of combination (Obstfeld, 2005; Obstfeld et al., 2014).

The tertius iungens concept accounts for entrepreneurial activity in an open network, “introducing disconnected individuals," as well as in a closed or dense network, "facilitating new coordination between [previously] connected individuals" (Obstfeld 2005: 100). This brokerage-as-process approach emphasizes the triad as a basic unit of network structure underpinning combinatorial action (Obstfeld, Borgatti, and Davis, 2014), although such initial combinations might include more than three actors (Simmel and Wolf, 1950).

Our theorizing emphasizes that the dominant activity associated with the entrepreneurial startup involves tertius iungens combinatorial connecting. We strengthen this focus, per the most recent theorizing about brokerage process (Obstfeld et al., 2014), with recognition that the pursuit of entrepreneurial trajectories relies on the deployment of multiple brokerage orientations: tertius iungens, tertius gaudens (i.e., a separation of actors whom the entrepreneur may want to temporarily or permanently keep apart), and conduit brokerage (i.e., 
the transfer of knowledge from one location or stakeholder to another, often to enhance some aspect of the emerging venture) (Long Lingo and O'Mahony, 2010). Social skill for entrepreneurs involves principally the ability to connect people (Baron and Markman, 2000; Fligstein and McAdam, 2012) but also to select and sequence the brokerage orientations mentioned above (Obstfeld et al., 2014).

The assembly perspective builds on but also challenges a well-developed assertion in the network literature emphasizing social network structure as a key factor that enables and constrains action. The assembly perspective treats network structure (e.g., number of ties, structural holes, centrality) as an important social infrastructure through which knowledge and opportunities are accessed but holds that an entrepreneur's network alone does not drive social network action.

Obstfeld and colleagues (2014) have extended this process-based view to the concept of brokerage. The structural view of brokerage emphasized in the social network literature involves an actor (or organization) who stands between two other actors, who themselves are not tied to each other. Obstfeld et al. (2014:141) define brokerage, however, as a process: "behavior by which an actor influences, manages, or facilitates interactions between other actors." This process-based definition might involve the open networks associated with structural holes but also involves facilitation and recombination within dense networks, where many of the nodes or actors involved have ties to one another.

The two mechanisms described thus far-knowledge articulation and combinatorial action - are pursued jointly and in pursuit of the projection that motivates the action. The connection between knowledge articulation and combinatorial action often involves a story, analogy, or metaphor (i.e., knowledge articulation) that is instrumental in motivating a nexus of interested parties to meet or act together. In support of this, Obstfeld (2017) provides 
preliminary empirical evidence that knowledge articulation in the form of analogies, metaphors, and stories correlates highly with the tertius iungens behavioral orientation. When successfully orchestrated, the pursuit of these two mechanisms often leads to the next element in our model, network expansion.

\section{Network expansion}

The fourth element of the assembly perspective concerns the expanded networks stemming from both knowledge articulation and combinatorial action. The entrepreneurial network expands through three interlocking forms of network-based activity: 1) ties created or subsequently strengthened though the articulation of the entrepreneurial projection; 2) network combinations of interested parties in various forms that often expand as they accrue additional participants; and 3) sequences of introductions and combinations over time, whereby one relational tie or combination leads to other combinations or ties. In network expansion, action unfolds through these forms over time, forming an open-ended pathway or set of pathways that, taken together, constitute the entrepreneurial project. Below we elaborate on these four interlocking forms of network-based activity.

First, network expansion emerges as actors create and subsequently strengthen ties (Mariotti and Delbridge, 2012; Elfring and Hulsink, 2007; Hallen and Eisenhardt, 2012; Vissa, 2011; Vissa, 2012) by communicating the entrepreneurial projection and related issues, often translating to make them relevant to the audience at hand. This activity, in social network terms, is dyadic in that it results from the entrepreneur's reaching out to actors, through planned or unplanned contact, to describe the entrepreneurial project. Such introductions might occur in meetings, conferences, and entrepreneurial events (Stam, 2010). A follow-up meeting to further develop an existing relational tie, by discussing the entrepreneurial venture's progress or pivots, and where trust or mutual understanding could be further enhanced, also 
falls into this category. A pitch to an audience, whether venture capitalists or angel investors, would also fall into this action category. Each audience member who attends the presentation (and may chat with the entrepreneur after the presentation) forms a tie with the entrepreneur.

One of the orienting claims here is that entrepreneurs regularly create new dyadic ties. We argue that these dyadic ties serve as the raw material upon which triadic-based network expansion relies. Across these many routinely-created new dyadic ties, we call particular attention to the "minimally viable ties" (MVTs), that is, those entrepreneurial ties that are more actionable going forward due to their salience for the project trajectory. We define an MVT as a tie stemming from a social engagement whereby the entrepreneur establishes a minimal sense of someone else's identity and interests sufficient for the entrepreneur to return to that person for a second conversation or to introduce that person to another in the future. We illustrate the role of MVTs in TT2 and TT3, where the entrepreneur's creation of new ties helps shape and reshape the venture. Such ties may grow in strength if they become reciprocal, in the sense that a minimal exchange occurs between the entrepreneur and one or more stakeholders. Over time, such minimal ties might evolve to include activities such as information exchange or knowledge sharing, advice, friendship, and even mentorship. Of critical concern is the extent to which the entrepreneur generates new resources through novel or heterogeneous ties or simply relies on pre-existing and more-familiar ties (Stam, 2010; Mariotti and Delbridge, 2012).

Second, network expansion continues as the entrepreneur engages not only dyadic ties but also multiple triadic ties in the form of combinations of interested parties that emerge in various forms. The entrepreneurial core of an organization often forms through such a combination. For example, Ruef (2010) describes an entrepreneur, Luis Hernandez, who persuades two collaborators, Bill Shipley and Diego Ramon, to begin a wholesale business for women's and children's clothing. As the entrepreneur reaches out to different people, he or she 
accumulates a portfolio of dyadic ties (Elfring and Hulsnink, 2007; Vissa and Chacar, 2009; Vissa, 2011), each of which may introduce recognized or unforeseen resources and interests. With those ties in mind, the entrepreneur puzzles over her projection, how it might evolve, or the means for moving toward it, and considers the various people she might introduce in order to create clusters of feedback, support, and expertise, on an unfolding entrepreneurial pathway.

Network combination, moreover, does not proceed exclusively as the initial combination of three or more actors but expands as simple combinations add participants. This expansion through the addition of ties often reflects how a core group of entrepreneurs grows initially. In his typology of entrepreneurial organizations, Ruef (2010) refers to this as the "open group," in which existing members display a strong, durable propensity to recruit further members, and he asserts that "entrepreneurial partnerships are generally formed as open groups." Note that not only the core or founding entrepreneurial group but the other combinations assembled by the entrepreneur might also expand in this manner.

Third, network expansion occurs via sequences of introductions and combinations over time, where one relational tie or combination leads to a subsequent introduction, which generates other ties or combinations. New introductions or combinations may emerge over time serially, with one introduction leading to new ties or combinations of actors, and in parallel whereby new ties and combinations of actors develop simultaneously on multiple fronts. The cumulative effect of such network expansion means increased participation, increased access to knowledge and resources through which the entrepreneur can further revise and develop the entrepreneurial projection, and, potentially, increased momentum toward an entrepreneurial goal.

\section{The four network elements in the assembly model}


We now explore how the elements in the conceptual model of assembly interact and their implications for entrepreneurial action. The entrepreneurial process begins with the emergence of the entrepreneurial projection, which, consistent with creation and sensemaking theory, begins with a variation in the environment. This variation might appear as an anomaly, puzzle, or a problem that interrupts an actor's ongoing routine or automatic engagement with the world. The actor converts that issue to a provisional solution that motivates and guides subsequent network-based action.

The entrepreneur engages existing and new network ties in the articulation of the tentative entrepreneurial projection, creating dialogue about the projection, its features and goals, and subsequent actions to take. While communicating the projection, the entrepreneur also creates links between existing and newly formed ties - that is, combination — to test ideas and mobilize support. An early combination of actors may constitute the venture's core leadership team. Other combinations may link constellations of support with similar or crossfunctional origins, each of which assemble support for the fledgling venture. As noted, every combination involves skillful choices at each point in the venture regarding with whom to connect, when to connect them, and, by inference, whom to leave out (i.e., the tertius gaudens orientation). Through this assembly of various combinations of ties (versus merely the formation of dyadic ties alone), an entrepreneur creates and expands the network that surrounds the evolving venture and propels it forward.

Finally, the entrepreneurial projection serves both as an idea or goal that motivates and guides action through the assembly process before combinatorial action, and also as a conceptual tool through which the entrepreneur often forms network combinations. In the first case, the projection precedes combinatory action, guiding the entrepreneur's search for knowledge, feedback, advice, resources, and support. Also "prior" to combinatorial action, 
knowledge articulation will be the means by which the entrepreneur brings the entrepreneurial projection to the attention of people he or she engages within his or her network. During combinatorial action, the projection may also serve as a means by which the entrepreneur identifies and forges common interests, meanings, and identities between other parties (Fligstein, 1997).

\section{THE ASSEMBLY PERSPECTIVE IN ACTION: A STYLIZED VIGNETTE}

To illustrate how the assembly perspective provides a conceptually useful basis for theorizing emergent entrepreneurial activity, we offer a stylized vignette, developed in some detail and with an accompanying set of illustrations. The vignette describes an entrepreneur, Julie, who has an idea for a new cell phone application, "Walk the Dog" (WTD), which links dog owners and dog walkers. Figure 2 depicts this illustration in sequential, cartoon-strip fashion. At several points we provide a "counterfactual" to the story, as it unfolds, to indicate not only what a creative project entails but also the action that does not occur and how its absence might undermine or redirect the eventual project.

------ Insert Figure 2 about here ------

Julie's initial vision of a WTD application is, in terms of the assembly perspective, an entrepreneurial projection. Note that the WTD business model itself focuses on a "metacombination" intended to link dog owners (depicted as carrying briefcases in TT1) to dog walkers (depicted as wearing baseball caps) through a phone app. ${ }^{3}$ This entrepreneurial projection emerged as Julie encountered the challenge of finding someone to walk her own dog and then discussed the challenge with friends and family. Through these discussions, the idea

\footnotetext{
${ }^{3}$ One could the claim that the cell phone application itself also serves as the tertius, linking dog owners and dog walkers, but for our purposes here we will restrict the tertius concept to human brokers.
} 
of a WTD app as a potential solution is hatched, along with the idea of Julie spearheading a venture that could create it. Once fully formed as a goal, the WTD application constitutes the entrepreneurial projection that motivates and guides Julie's future action. Julie's provisional crystallization of the WTD projection as a successful phone app motivates her to act to acquire the necessary knowledge, resources, collaborations, and support; most immediately, it guides her choices regarding with whom to interact or collaborate next to move toward animating the trajectory.

We could posit several alternatives to Julie's creation of an entrepreneurial projection that motivates and guides her subsequent entrepreneurial action: Julie may form a projection that seems promising but, for many possible reasons, fails to motivate further action. Perhaps, after preliminary exploratory conversations, she fails to receive a sufficiently positive response from early interlocutors (e.g., family and friends, potential collaborators, other entrepreneurs, b-school professors) to judge the project as sufficiently promising to pursue. Another alternative is the absence of an entrepreneurial projection altogether; that is, some actors may never fully notice and bracket the problem (Weick et al., 2005) or contemplate a solution in terms of any kind of venture. Such a counterfactual might involve an actor who fails to link the environmental anomaly (i.e., the absence of dog walkers) to the possibility of a new venture. Other actors might briefly entertain project-like opportunities but do not forge them into actionable projects. Such actors may never engage entrepreneurship as an identity. Finally, we know that entrepreneurial dispositions to act in the face of adversity vary; some will not pursue a project if they receive negative feedback that calls into question the merits of the entrepreneurial projection (see TT1).

In the WTD case, the need to access new input and resources for the concept drives Julie to do further internet research, articulate the entrepreneurial projection to her friends and 
to reach out to new stakeholders (see TT2). Julie attends a local tech meet-up, mindful of her need for financial, technical, and marketing knowledge and support. Motivated by the desire to generate knowledge and to progress toward her entrepreneurial projection, she articulates the WTD projection first to Arlo, an angel investor, and later in the meet-up, to Piper, a programmer. Her representation of the overall purpose and prospects for the WTD app includes not only a general narrative of how the product solves problems, but she also translates the projection to address the different interests of various stakeholders.

The means by which Julie pursues the creation of the phone app will also involve a series of unfolding combinatorial connections of people and resources. In this case, Julie envisions that Arlo and Piper might form the nexus of WTD. This combinatorial action constitutes a first step in Julie's entrepreneurial-project trajectory. Julie pursues Arlo for the funding resources that he controls and Piper for her programming skills. This illustrates how, in entrepreneurial settings, triadic combining (i.e., bringing people together) is often motivated by the potential created through bringing together the resources, skills, and ideas that people hold. For the next step, Julie invites Arlo and Piper to a lunch meeting in efforts to create a founding triad (see "Founding Triad" in TT2). Julie attempts to form WTD's founding team by articulating a narrative of business growth and meaning in a way that appeals jointly to the actors involved. Julie may not bring her investor, Arlo, fully into the fold until he meets the rest of Julie's management team, at which point the startup's mission and accomplishments are shared, discussed, and ratified.

One can easily imagine several iterations of this story. Arlo, for example, might be interested in investing, but Piper may turn out to be underqualified, uninterested, or disliked by Arlo, leading Julie to interview other candidates. Julie may hire Piper and a second programmer, Lin, through one-on-one interviews but will eventually need to introduce and 
coordinate their work as employees or contractors. Julie, as the tertius, will initiate other triadic meetings as the fundamental means of creating and scaling her business. Note also how the WTD entrepreneurial projection is not fixed but, rather, has evolved, as shown in TT2, to a new version, $\mathrm{WTD}_{\mathrm{B}}$ as Julie encounters new insights, resources, and constraints.

The counterfactual to Julie's early "success" might involve a choice of collaborators who substantially limit Julie's progress. Collaborators, broadly understood, could be the random contacts she makes, the advisors she identifies, and the initial people with whom she partners more regularly to get project work done. Perhaps Julie chooses Piper, her first programmer, settling on her prematurely perhaps because she is a friend or in response to her general congeniality. As a first-time entrepreneur or someone new to a given professional context, she may also inappropriately choose Piper due to an absence of critical knowledge and judgment regarding what constitutes a good choice for her startup. Such mistakes might multiply if she makes poor choices about other early collaborators. In addition, Julie may hire people who are competent individuals but fit together poorly. Such a consideration sounds suspiciously like an old but true bromide regarding the importance of hiring a good entrepreneurial team, except the team in this case is not fixed in the traditional sense; it is a dynamic entity that will expand and evolve in multiple unforeseen directions. Julie may possess limited anticipation of that emerging collaborative imperative or limited instincts on how to cultivate the rapport that fosters growing collaboration.

Having emphasized the importance of Julie's entrepreneurial projection, we also stress the tension created by the dynamic interaction between the projection (the ends of her entrepreneurial action) and the means for reaching the projection. As noted, we refer to this tension as "evolving means and ends." The properties of Julie's entrepreneurial projection are expected to evolve over time in response to continual feedback generated by her efforts. Arlo 
may be willing to invest only on the condition that the phone application includes functionality for connecting cat owners and cat walkers. Julie may adjust or refocus (i.e., "pivots") the initial entrepreneurial projection, to secure Arlo's participation. If so, Julie's projection might evolve to a revised and expanded entrepreneurial projection, Walk the Pet. Figure 2 reflects an evolution of the WTD projection's trajectory from its original form, WTD, in TT1, to WTDE, in TT5. A counterfactual here might involve an entrepreneur unwilling or unable to make adjustments, in the form of potential pivots, to the entrepreneurial projection. The entrepreneur might hold to a given set of features, regardless, refusing to adapt due to her identification with the original projection (Grimes, 2017). Alternatively, she may adapt so frequently that the resulting project loses the support of investors or employees.

Imagine that Julie's initial success in bringing people together and pushing the project forward increases the need for programmers and, consequently, funding, which Arlo is unable or unwilling to provide. Julie's startup efforts will now involve triadic connecting of additional programmers and investors to the core cluster, which will reflect a nexus of actors greater than three, ${ }^{4}$ or network expansion (see "Expanded Triad" in TT3). The entrepreneurial projection that motivates and guides network action has now evolved to $\mathrm{WTD}_{\mathrm{C}}$. This network expansion is early and might continue as Julie and her core team expands both the WTD organization itself and the proximate network though the creation of new ties.

Julie articulates the WTD entrepreneurial projection simultaneously with her orchestration of networks. Julie's narrative not only evolves along with her business model but is shaped and re-shaped in response to the stakeholders she engages at any given moment. What Julie presents to any investor or stakeholder may be "derivative" of the core

\footnotetext{
${ }^{4}$ Simmel (1950) pointed out that a key transition in social theory involves the shift from the dyad to the triad and that much larger numbers still drew on triadic-based phenomena.
} 
entrepreneurial idea, translated to appeal to a given stakeholder's specific interests (Fisher, Kuratko, Bloodgood and Hornsby, 2017; Nohria and Eccles 1992). She may present a narrative rich with financial terms and content to an investor and, later the same day, a technologythemed narrative to a tech-savvy programmer whom she may hire as a manager (see TT4). Ultimately, however, the core process of combination will rely on the enlisting of multiple actors through knowledge articulation, specifically, representational acts (e.g., metaphors, analogies, and stories) intended to generate successful collaborations through shared understanding among different clusters of people and their associated resources.

There are many substantive or subtle ways that Julie might fall short in her articulation skill. She may fail to discern the need to fashion different accounts of her fledgling success (or lack thereof) to the various stakeholders to whom she presents WTD; she may reliably give the same account to everyone who might ask. She may sense the need for different accounts and translations but fail to detect the subtleties of reading her interlocutors and tailoring her accounts to make them more compelling, including the jargon to emphasize or leave out, the length of a given account, and ongoing social cues that inform dialogue. These considerations point to the entrepreneur's level of social skill (Fligstein 2001).

The network expansion in the WTD case takes many forms. At a later stage, Julie's college friend, Jennah, reports that her close friend, Bruno, holds a central role in screening and approval of new applications for Apple App Store. Jennah subsequently introduces Julie to Bruno over coffee (see TT5). This act of joining suggests that although Julie initiated her iPhone app trajectory, she is not necessarily the only source of tertius-based linking but can benefit from linking provided by partners, friends, acquaintances, and people she hires. This new tertius linking also suggests the nature of a trajectory as a series of combinations over time - another form of network expansion—and the means by which entrepreneurial projects 
scale. It is not a foregone conclusion that Julie's effort will grow or succeed, but an emergent cascade of combinations would explain how such expansion would take place if it occurred. ${ }^{5}$ Julie's orchestration of networks involves multiple, simultaneous brokerage activities, along with action paths that evolve as certain byways open and others close (see TT6). In pursuit of a successful combination, Julie might invite appropriate parties (i.e., tertius iungens) and exclude others deemed unsuitable to the given collaborative task (i.e., tertius gaudens). Julie may deliberately delay bringing her new startup to the attention of her friend who is a VC (i.e., tertius gaudens) until the venture has more active users or is generating more revenue. She may invite certain iPhone entrepreneurs to a dinner to share information (i.e., iungens) but exclude other such entrepreneurs who she considers to be direct competitors (i.e., gaudens). From this perspective, according to assembly entrepreneurship, gaudens separation and conduit-based knowledge movement often accompany the iungens act.

Consider the act of timing inherent in Julie's actions: She might not introduce a programmer (one leg of the open social network triad) to her venture-capitalist friend (the second leg of the open social network triad) until she has consolidated trust in one or both of these relationships. The non-tie between the programmer and investor is one that Julie may consciously maintain through a strategy of separation. At some time in the future, however, the introduction might make sense, perhaps due to its increased probability of leading to a superior collaborative outcome, a strategic change from a gaudens to a iungens strategy over time.

\footnotetext{
${ }^{5}$ It turns out that an actual Walk the Dog business, "Wag!", emerged after this article was originally drafted. A critical move for Wag! was the adaptation of a crowd-sourced, peer-to-peer ranking system whereby customers rank the services provided by dog walkers. Julie might fail to see the need for such a peer-to-peer ranking system, fail to create combinations of actors who bring such possibilities to her attention, fail to recognize the importance of a peer ranking system, or adapt such a system too late. We assume that the general ability to make the right adjustments to the entrepreneurial design, at the right time, is critical to Julie's ongoing progress. See "Jolly (2015) "Dog needs a walk? There's an app for that," NYT: https://well.blogs.nytimes.com/2015/07/07/dog-needsa-walk-theres-an-app-for-that/
} 
TT6 suggests other twists and turns characteristic of an entrepreneurial trajectory. One twist might be an unforeseen introduction that leads to the opportunistic hire of a third programmer in AI, who can use such programming to match dog walkers and dog owners. This hire might also be a response to a key investor, who expressed interest in more technologically-motivated features. A marketing candidate might turn WTD down for a job with Lyft while a second marketing candidate joins because of a friend in the core team. These calculations about which combinations to pursue, postpone, or avoid, along with the awareness that some combinations take hold and others fail, reflect the uncertainty of entrepreneurial action. The vignette ends on a guardedly optimistic note with WTD moving out of Julie's basement and into a coworking space.

\section{Conceptual insights from the stylized vignette}

The vignette illustrates important conceptual insights about the assembly perspective of entrepreneurial action. First, an entrepreneurial effort will almost always begin with some external variation or anomaly, in this case, Julie's difficulty in locating someone to walk her dog while she is at work. As the problem and solution provisionally crystallize for Julie, so does her provisional identity as an entrepreneur. Second, entrepreneurs must rely on knowledge articulation, discursive or representational practices to frame, clarify, revise, and contextualize goals, in order to mitigate uncertainty and propel action forward. Third, the entrepreneur's efforts will involve numerous combinatorial episodes in which the entrepreneur attempts to link people and resources in various ways. In many cases, such combinations of actors provide social settings with which to continue to test, revise, and update the entrepreneurial projection. Because novelty and high uncertainty characterize the combinations associated with an entrepreneurial project, the entrepreneur will rely on knowledge articulation for coordinating and integrating parties in the absence of well-established routines. Some of 
these combinatorial episodes are successfully realized and some fail, for various reasons. Multiple combinatorial processes and variants are hallmarks of successful early-stage entrepreneurial endeavors, which is why we refer to network expansion as occurring along an unfolding path or action trajectory.

Finally, the pursuit of early-stage entrepreneurial projects requires social skill. Beyond the considerable accomplishment of consolidating an entrepreneurial projection that is sufficient to motivate and guide an entrepreneur's action, social skill is comprised of the ability to communicate ideas alongside the ability to "induce cooperation" between parties across one's network (Fligstein, 2001: 106; Fligstein and McAdam, 2012). Articulating a projection in a manner that elicits interest, knowledge sharing, and participation among widely varying audiences while simultaneously determining whom to connect and when to connect them is a function of considerable social skill. The entrepreneur constantly makes such choices in translation and timing in order to foster and propel a project's trajectory. This conceptualization of social skill as involving both skillful communication (i.e., knowledge articulation) and network combination corresponds to Padgett and Ansell's (1993) view of robust action: a broker's ability to act strategically within a network by displaying different beliefs, identities, and voices (i.e., multivocality) to actors in different network positions, as necessary, to cultivate the most strategically advantageous action. It is also worth noting that social skill is unevenly distributed; actors will possess different access to networks, resources, and the skill to orchestrate them for their projections. In related terms, actors will display different capacities to learn, that is, to acquire social skill and build access to networks and resources. 


\section{DISCUSSION}

Davis (2017) recently grappled with the implications of the "uberization" of the economy, whereby tasks and functions that integrated organizations previously performed are now often disaggregated and linked by different forms of digital and market coordination. To address this shift, Davis calls for increased emphasis on the organizing processes that make these new forms possible, arguing, "[We] need to get the ontology right. If organization theory is to be useful, it has to stop being too attached to organizations and be more attentive to how organizing happens" (p. 321). Our approach to incipient organizing not only characterizes the startup mechanisms found in a broad range of domains but also speaks to the new forms of coordinative action that Davis describes. Tracing empirical ways to address such phenomena, Davis (2017: 319) notes, "Network analysis comes closest to addressing fields as a system of relations ..., but even network research typically imagines relations as 'on' or 'off' rather than continuously shifting." To fully realize the potential to generate, through a network perspective, new insight on entrepreneurship and, ultimately, other forms of distributed organizing, we offer the assembly perspective of entrepreneurial action.

Important arguments in entrepreneurship theory and research focus on the nature of entrepreneurial opportunities (Alvarez and Barney, 2007) and the actions associated with the pursuit of such opportunities (Baker and Nelson, 2005; Sarasvathy, 2001, 2008). Underpinning all this work is the assumption that entrepreneurs have and leverage social networks; yet, the primary social-action approaches in entrepreneurship research do not specify the assembly and dynamics of such networks. Our theoretical perspective accounts for the microsocial action that is associated with network origination and evolution in the context of entrepreneurial projects. The commonalities among the theoretical perspectives accounting for entrepreneurial action have received limited research attention (Fisher, 2012). We view networks and network actions 
as elements that connect these different perspectives, and construct an integrative model accounting for network processes and the role of the tertius iungens. We make explicit the combinatorial action and knowledge-articulation work that orchestrate early-stage entrepreneurial projects motivated and guided by an entrepreneurial projection. As a result, we provide new creative, project-focused insights into underexplored and disparate elements in the canon of entrepreneurship research. The assembly perspective developed here generates new insight into similarities and differences between other action-oriented theories of entrepreneurship: bricolage, effectuation, and creation. It also offers partial resolutions to particular debates that have emerged within these perspectives. We discuss these insights and resolutions below.

\section{Assembly perspective, bricolage, effectuation, and creation}

The assembly perspective of entrepreneurship makes it possible to integrate and advance core network-based insights found in the bricolage, effectuation, and creation theory lines of entrepreneurial-action theory and research. Our focus on the central role of networks and network-based action in entrepreneurial startups serves to contrast, integrate, and support these other approaches. Table 2 summarizes the relationship of our assembly perspective to those approaches. The table compares certain key dimensions: core definitions, the dominant mechanisms underpinning action, the outcomes of action, the focal process that characterizes the approach, the forms of expertise and social skill used, and the explicit role of networks.

------Insert Table 2 about here------

\section{Assembly perspective and effectuation}

The assembly perspective accommodates both the primacy of networks and the improvisational engagement of action found in effectuation theory, but our perspective asserts a more central role for the evolution of projections that emerge, at some point in the field of action, to 
meaningfully motivate and guide action. Effectuation theory's contention that entrepreneurs begin not with goals but with "who I am," "what I know," and "who I know" as three fundamental categories of means (Sarasvathy, 2008) corresponds to our theory's emphasis on networks and knowledge as key resources with which an entrepreneur engages new action. As noted, however, we explicitly pair social network theory's traditional emphasis on network structure and knowledge with two core social processes, network combination and knowledge articulation, respectively, which entrepreneurs use to mobilize action.

The idea of an evolving path of action comprising a sequence of combinatorial episodes appears to correspond roughly with what Sarasvathy and Dew (2005), within effectuation theory, describe as entrepreneurial growth that occurs through a chain of effectual "commitments" by which the entrepreneur forms partnerships that reduce uncertainty (the Patchwork Quilt principle). Effectuation theory describes commitments "as contracting along certain dimensions for the future" in order to "destroy uncertainty" (Sarasvathy, 2008:88). Although the nature of such commitments is not entirely specified, they appear to be dyadic arrangements that are more binding than simple "interactions," as in Sarasvathy and Dew's (2005) example of an entrepreneur willing to modify the features of a new product in exchange for a customer's payment or investment.

Our assembly approach stresses a triadic view of network phenomena through which an entrepreneur constructs networks of support. This perspective often includes the formation of dyadic ties in the form of new introductions or as part of a sales process but ultimately emphasizes the creation of various triadic combinations. Furthermore, an assembly perspective describes how entrepreneurs navigate their network, emphasizing their deliberate pursuit of an entrepreneurial projection through a sequence of combinatorial action that, if successful, produces new venture growth. 
If, as we have argued, the entrepreneurial projection is crucial for motivating and guiding action through a sequence of combinations of people, resources, and ideas that the entrepreneur orchestrates, we must then account for the existence of purposeful behavior and unscripted surprises that can redirect action. An entrepreneur curates among people, resources, and ideas, while allowing for surprises to introduce new possible elements and combinations. We argue that the entrepreneurial projection typically informs the entrepreneur about which elements will be most important at the next set of combinatorial junctures. For example, an entrepreneur considering a project ("Q") searches for people, resources, and ideas necessary to advance the project. The entrepreneur, in effect, engages their environment with the project $Q$ in mind, cross-examining both existing and newly found contexts for people, resources, and ideas that he or she can fruitfully combine in different ways to support the emergent effort. Choice in this case concerns a series of decisions to bring certain elements (i.e., people, resources, and ideas) together and not others, in pursuit of the entrepreneurial goal. Our assembly perspective also assumes that the ends (i.e., the entrepreneurial projection) may evolve as the means for moving action forward unfold.

\section{Assembly perspective and bricolage}

The assembly perspective allows us to fruitfully reframe the bricolage process of resource combination as a broader social network process of actors joining actors and the resources they bear. In related terms, Baker and colleagues' (2003) emphasis on entrepreneurial activity within "pre-existing networks" as "network bricolage" might mask a broader set of network considerations that underlie combinatorial activity. Consider a relatively basic distinction: networks may vary by their size and the extent to which they are open, that is, have many structural holes (Burt, 1992), or closed, that is, dense. The pre-existing contact network to which Baker and colleagues (2003) refer may apply equally to a large, open 
network full of diverse actors and resources or to a small, closed network with homogenous actors and resources.

While the bricolage literature fruitfully shifted emphasis to combinations involving existing resources and networks, such networks could range from small, dense, homogenous networks to large, open, and more heterogeneous networks, and anything in between. If an entrepreneur exhibits a broad range of combinatorial activity across a more diverse array of combinatorial elements, the sense of working with people and resources "at hand" takes on a very different meaning that is ripe for further empirical investigation. In addition, Baker and colleagues' (2003) concept of a pre-existing network skirts the consideration that networks are dynamic and constantly evolving. If an entrepreneur adds multiple ties to her network over a series of years, it is unclear which network and combinatorial action qualify as pre-existing.

Mindful of these distinctions, we extend the bricolage literature's emphasis on combination within pre-existing networks to consider combination in large and small, or open and closed, networks with a blend of existing or newly emerging social network ties. This approach allows us to consider combinatorial action in diverse, heterogeneous, and dynamic environments. In such contexts, for example, pre-existing ties and resources might be combined with newly created ties and resources. An entrepreneur might start with novel resources and then settle into more predictable combinations within a stable network or, alternatively, combine people and resources within a stable, dense network until he or she encounters an "outlier" who opens up a new world of ties and resources; as a result, the network then goes from having stable, familiar elements and combinations to a more dynamic network with a greater number of unfamiliar elements and, consequently, more unpredictable combinations. This approach also accommodates a hybrid case in which, for example, an entrepreneur might combine ten pre-existing resources with one newly discovered and, hence, 
more exotic resource. These distinctions indicate important network-based, independent variables that suggest valuable new opportunities for future empirical investigation.

The bricolage perspective also suggests a broad temporal orientation. Regarding the bricoleur's temporal orientation, Levi-Strauss (1966:18) suggests that the bricoleur's first practical step is retrospective. He has to turn back to an already existent set made up of tools and materials, to consider or reconsider what it contains and, finally, above all, to engage in a sort of dialogue with it and, before choosing between them, to index the possible answer which the whole set can offer to his problem.

Toward that end, according to Levi-Strauss (1966: 18), the bricoleur "interrogates all the heterogeneous objects of which his 'treasury' is composed to discover what each of them could 'signify' and so contribute..." From a broader perspective, however, we argue that the entrepreneur as bricoleur and sense-maker is looking both backward at existing resources and forward toward what he or she wishes to create (Weick et al., 2005.) The entrepreneur's first step may, indeed, be retrospective, interrogating existing combinatorial elements (based on his or her experience with them) to be cognizant of the possibilities they afford, individually or in different combinations.

It is equally likely, however, as Levi-Strauss indicates, that the bricoleur interrogates with his or her "problem" in mind. Interrogating existing resources and mindful of the problem motivating the interrogation, the bricoleur looks both backward in time at the history and past uses of resources and forward toward the potential solutions he or she may fashion. For the entrepreneur, that potential solution takes the form of the entrepreneurial projection and different intermediate steps to reach it. The bricoleur, therefore, serves as both a resource and temporal tertius brokering among different resources that he or she combines and among the past, present, and future in order to move the project forward. In sum, we suggest that the 
entrepreneur, in the pursuit of moving projects forward, looks within and outside of his or her network as well as backward and forward in time.

\section{Assembly perspective and creation theory}

Creation theory is a more recent entrepreneurial perspective to emerge in the literature. It emphasizes the creation of opportunities, in contrast to a discovery perspective, which posits that those opportunities already exist and merely need to be located and leveraged. The influence of creation theory has grown, as process theories have recognized the importance of navigating the uncertainty and ambiguity inherent in many entrepreneurial ventures. Creation theory's emphasis on enactment has also placed evolutionary and sensemaking-based theories

at the center of the entrepreneurial process. This emphasis focuses on the social construction of opportunities and the extent to which the entrepreneur engages uncertainty in the earliest entrepreneurial stages. Creation theory's foundational emphasis on these processes also creates an opening to revisit the nature of entrepreneurial goals and motivation. In particular, we employ creation theory's framing to describe how the entrepreneur provisionally identifies variations and anomalies to form constellations of problems and solutions, which evolve into provisional projections that motivate and guide entrepreneurial action.

This extension suggests ways to revisit aspects of creation theory. One tenet of creation theory involves the potential lack of differences between those who do and do not create opportunities (Alvarez and Barney, 2007), by emphasizing small differences between what leads some to form opportunities and others not to form them. One basis for those differences, Alvarez and Barney (2007) suggest, might be variations in an entrepreneur's local environment. We argue, in terms of an evolutionary and enactment process, that relatively subtle differences between the creation or non-creation of opportunities might hinge on earlystage noticing and bracketing of environmental variations and a readiness to enact provisional 
entrepreneurial projections that register those differences. Those same distinctions may lead entrepreneurs to engage existing and new ties in response to their early provisional projections. These distinctions suggest a closer look at how such early-stage enactment processes lead to the creation of opportunities. In any case, an enactment perspective suggests why the ex ante distinctions between those who create opportunities and those who do not might be hard to identify through traditional parameters. This also suggests another means by which an actor's attention can be cultivated to perceive and act on emergent opportunities - an atypical arena for the development of entrepreneurial capability.

A second tenet of creation theory is to question the assumed centrality of decisionmaking in uncertain contexts (Alvarez and Barney, 2007). In such uncertain contexts, creation theory argues, the difficulty of collecting and analyzing information renders traditional decision-making considerably less important (Alvarez and Barney, 2007). Adopting the assembly perspective, we suggest that decision-making or choice may shift from a computational emphasis to a relational emphasis. With this latter emphasis, the key "decisions" involve an actor's decision to bracket and engage in the pursuit of an entrepreneurial projection, then the decision of whom to engage in his or her network, which combinations to create and which to avoid, how to translate the entrepreneurial projection to engage network actors, and when to engage such actors as the entrepreneurial action trajectory unfolds.

\section{Conclusion}

In summary, we present an assembly perspective on entrepreneurial action as a vehicle for explaining the development of social networks surrounding entrepreneurial projects. The framework integrates the foundational perspectives at the vanguard of social-action entrepreneurial research, while suggesting ways to extend an integrated, action- and social network-based view of entrepreneurship. We emphasize action across time while allowing for 
emergent means and ends. Entrepreneurs, in our view, have goals and intentionality, but entrepreneurial action cannot be explained by a novel goal, plan, or intriguing combination of elements alone. Similarly, a broker's recognition of an unrealized gap or opportunity is not a full explanation of entrepreneurship because it does not account for the ensuing path of network-based action that must unfold for an entrepreneurial projection to be realized.

The greater uncertainty associated with entrepreneurial projects points to a sensemaking orientation in which the answers to "what's going on here?" and "what do we do next?” are not yet known (Weick et al., 2005). We emphasize intimate, small-numbers, microsocial-action arenas in which the ongoing work is to make sense and take action to open up further possibilities that resonate with the entrepreneurial projection. These small-numbers interaction contexts are especially relevant for early-stage ventures, in which novelty and uncertainty are most prominent. The scaling and stabilization of entrepreneurial ventures likely prompts the emergence and rationalization of certain organizational routines, which is an outcome to be explored and that goes beyond the assembly-based framework presented here.

Future research can help to differentiate types of entrepreneurial-project trajectories. Such trajectories, differentiated by the sequencing of people, resources, and idea combinations, may help to explain success and failure as well as the rapid and slow growth of new ventures. In empirical terms, such research may identify ways to differentiate the network origin, size, density (or structural holes), and relative heterogeneity of combinatorial elements (people, ideas, and resources) over time that are most suited, for example, to disruptive versus more incremental innovation.

Entrepreneurial projects entail people doing new things together. The assembly perspective provides concepts and a process model resonant with the "how" of entrepreneurial activity and the social networks underpinning such activity. Accounting for the ways in which 
actors create networks as they pursue entrepreneurial projects, we provide a compelling process-based perspective of the social aspects of entrepreneurship and the value created therefrom.

\section{REFERENCES}

Alvarez SA, Barney JB, Anderson P. 2013. Forming and exploiting opportunities: The implications of discovery and creation processes for entrepreneurial and organizational research. Organization Science 24: 301-317.

Alvarez SA, Barney JB. 2007. Discovery and creation: Alternative theories of entrepreneurial action. Strategic Entrepreneurship Journal 1: 11-26.

Alvarez SA., Barney, JB. 2010. Entrepreneurship and epistemology: The philosophical underpinnings of the study of entrepreneurial opportunities. Academy of Management Annals, 4: 557-583.

Alvarez SA, Busenitz LW. 2001. The entrepreneurship of resource-based theory. Journal of Management 27: 755-775.

Alvarez SA., Young SL, Woolley, JL. 2015. Opportunities and institutions: A co-creation story of the king crab industry. Journal of Business Venturing, 30: 95-112.

Baker T, Miner A, Eesley D. 2003. Improvising firms: Bricolage, retrospective interpretation and improvisational competencies in the founding process. Research Policy 32: 255-276.

Baker T, Nelson RE. 2005. Creating something from nothing: Resource construction through entrepreneurial bricolage. Administrative Science Quarterly 50: 329-366.

Baron RA, Markman, GD. 2000. Beyond social capital: How social skills can enhance entrepreneurs' success. Academy of Management Perspectives, 14(1), 106-116.

Becker HS. 1986. Doing Things Together: Selected Essays. Evanston, IL: Northwestern University Press.

Blank S. 2013. Why the lean start-up changes everything. Harvard Business Review 91(5): 63-72.

Brown JS, Duguid P. 2001. Knowledge and organization: A social-practice perspective. Organization Science 12: 198-213.

Brush CG, Greene PG, Hart MM. 2001. From initial idea to unique advantage: The entrepreneurial challenge of constructing a resource base. Academy of Management Perspectives, 15: 64-78.

Burt RS. 1992. Structural Holes: The Social Structure of Competition. Harvard University Press: Cambridge, MA. 
Cooney T. 2005. What is an entrepreneurial team? International Small Business Journal, 23: 226-235.

Davidsson P, Honig B. 2003. The role of social and human capital among nascent entrepreneurs. Journal of Business Venturing 18: 301-331.

Davis GF. 2017. Organization theory and the dilemmas of a post-corporate economy. In How Institutions Matter! (pp. 311-322). Emerald Group Publishing Limited.

Dewey J. 2002. Human Nature and Conduct. Prometheus: Amherst, MA (originally published 1922).

Eccles, RG, Nohria, GN, Berkley, JD. 1992. Beyond the Hype: Rediscovering the Essence of Management: Boston, Harvard Business School Press.

Eckhardt JT, Shane SA. 2003. Opportunities and entrepreneurship. Journal of Management 29: 333-349.

Eisenhardt KM, Schoonhoven CB. 1996. Resource-based view of strategic alliance formation: Strategic and social effects in entrepreneurial firms. Organization Science, 7: 136-150.

Elfring T, Hulsink W. 2007. Networking by entrepreneurs: Patterns of tie-formation in emerging organizations. Organization Studies, 28: 1849-1872.

Emirbayer M, Mische A. 1998. What is agency? American Journal of Sociology 103: 9621023.

Engel Y, Kaandorp M, Elfring T. 2017. Toward a dynamic process model of entrepreneurial networking under uncertainty. Journal of Business Venturing 32: 35-51.

Fang R, Chi L, Chen M, Baron RA. 2015. Bringing political skill into social networks: Findings from a field study of entrepreneurs. Journal of Management Studies, 52: 175-212.

Fisher, G, Kuratko, DF, Bloodgood, JM, Hornsby, JS. 2017. Legitimate to whom? The challenge of audience diversity and new venture legitimacy. Journal of Business Venturing, 32: $52-71$.

Fisher, G. 2012. Effectuation, causation, and bricolage: a behavioral comparison of emerging theories in entrepreneurship research. Entrepreneurship Theory and Practice 36: 1019-1051.

Fligstein, N. 2001. Social skill and the theory of fields. Sociological theory, 19: 105-125.

Fligstein N, McAdam D. 2012. A Theory of Fields. Oxford University Press.

Gartner WB, Bird BJ, Starr J. 1992. Acting as if: Differentiating entrepreneurial from organizational behavior. Entrepreneurship Theory and Practice 16(13): 13-32. 
Gartner WB. 1989. 'Who is an entrepreneur?' is the wrong question. Entrepreneurship Theory and Practice 13: 47- 68.

Garud R, Karnoe P. 2003. Bricolage versus breakthrough: Distributed and embedded agency in technology entrepreneurship. Research Policy 32: 277-300.

Gould R, Fernandez J. 1989. Structures of mediation: a formal approach to brokerage in transaction networks. Sociological Methodology, 89-126.

Hallen BL, Eisenhardt KM. 2012. Catalyzing strategies and efficient tie formation: How entrepreneurial firms obtain investment ties. Academy of Management Journal 55: 35-70.

Hallett T, Ventresca MJ. 2006. Inhabited institutions: social interactions and organizational forms in Gouldner's patterns of industrial bureaucracy. Theory and Society 35: 213-236.

Harper, DA. 2008. Towards a theory of entrepreneurial teams. Journal of Business Venturing. 23: 613-626.

Hoang H, Antoncic B. 2003. Network-based research in entrepreneurship: A critical review. Journal of Business Venturing 18: 165-187.

Hughes E. 1971. The Sociological Eye: Selected Papers. New Brunswick, NJ: Transaction Books.

Jarillo JC. 1989. Entrepreneurship and growth: The strategic use of external resources. Journal of Business Venturing, 4: 133-147.

Joas, H. 1996. The Creativity of Action. University of Chicago Press: Chicago.

Jolly, J. 2015. Dog needs a walk? There's an app for that," NYT:

https://well.blogs.nytimes.com/2015/07/07/dog-needs-a-walk-theres-an-app-for-that/

Levi-Strauss C. 1966. The Savage Mind. University of Chicago Press.

Long Lingo ES, O’Mahony S. 2010. Nexus work: Brokerage on creative projects. Administrative Science Quarterly 55 47-81.

Lounsbury M, Glynn MA. 2001. Cultural entrepreneurship: Stories, legitimacy, and the acquisition of resources. Strategic Management Journal, 22: 545-564.

Mariotti F, Delbridge R. 2012. Overcoming network overload and redundancy in interorganizational networks: The roles of potential and latent ties. Organization Science, 23: 511-528.

Marsden PV. 2002. Egocentric and sociocentric measures of network centrality. Social networks 24: 407-422 
McMullen JS, Shepherd DA. 2006. Entrepreneurial action and the role of uncertainty in the theory of the entrepreneur. Academy of Management Review 31: 132-152.

Obstfeld D, Borgatti S, Davis J. 2014. Brokerage as a Process: Decoupling Third Party Action from Social Network Structure. Research in the Sociology of Organizations.

Obstfeld D. 2012. Creative projects: A less-routine approach to getting new things done. Organization Science 23:1571-1592.

Obstfeld D. 2017. Getting new things done: Networks and the assembly of innovative action. Stanford University Press.

Obstfeld D. 2005. Social networks, the Tertius Iungens orientation, and involvement in innovation. Administrative Science Quarterly 50: 100-130.

Ozcan P, Eisenhardt KM. 2009. Origin of alliance portfolios: Entrepreneurs, network strategies, and firm performance. Academy of Management Journal 52: 246-279.

Ozgen E, Baron, RA. 2007. Social sources of information in opportunity recognition: Effects of mentors, industry networks, and professional forums. Journal of Business Venturing, 22(2): 174-192.

Padgett JF, Ansell CK. 1993. Robust action and the rise of the Medici, 1400-1434. American Journal of Sociology 98: 1259-1319.

Polanyi M. 1958. Personal Knowledge: Towards a Post-critical Philosophy. University of Chicago Press: Chicago.

Ries E. 2011. The lean startup: How today's entrepreneurs use continuous innovation to create radically successful businesses. Crown Business.

Robinson J. 2006. Navigating social and institutional barriers to markets: How social entrepreneurs identify and evaluate opportunities. Social Entrepreneurship. Palgrave Macmillan, London, 2006. 95-120.

Ruef M, Aldrich HE, Carter NM. 2003. The structure of founding teams: Homophily, strong ties, and isolation among US entrepreneurs. American Sociological Review, 195-222.

Ruef M. 2010. The Entrepreneurial Group: Social Identities, Relations, and Collective Action. Princeton, NJ: Princeton University Press.

Sarasvathy SD. Dew N. 2005. New market creation through transformation. Journal of Evolutionary Economics 15: 533-565.

Sarasvathy SD, 2008. Effectuation: elements of entrepreneurial expertise. Edward Elgar, Northhampton. 
Sarasvathy SD. 2001. Causation and effectuation: Toward a theoretical shift from economic inevitability to entrepreneurial contingency. Academy of Management Review, 26(2): 243263.

Schjoedt L, Monsen E, Pearson A, Barnett T, Chrisman JJ. 2013. New venture and family business teams: Understanding team formation, composition, behaviors, and performance. Entrepreneurship Theory and Practice, 37: 1-15.

Schumpeter JA. 1947. The creative response in economic history. The Journal of Economic History 7: 149-159.

Schumpeter JA. 1934. Theory of Economic Development. Harvard University Press: Cambridge, MA.

Schutz A. 1967. The Phenomenology of the Social World. Northwestern University Press.

Simmel G. 1950. The Sociology of Georg Simmel. Translated by Wolff KH. Free Press: Glencoe, IL.

Smith KG, DeGregorio D. 2002. Bisociation, discovery and the role of entrepreneurial action. In Strategic Entrepreneurship: Creating a New Integrated Mindset, Hitt MA, Ireland RD, Camp SM, Sexton DL (eds). Blackwell: Oxford, UK.

Stam W. 2010. Industry event participation and network brokerage among entrepreneurial ventures. Journal of Management Studies, 47: 625-653.

Stinchcombe AL. 1965. Social structure and organizations. In Handbook of Organizations, March JG (ed). Rand McNally: Chicago; 142-193.

Strauss A. 1988. The articulation of project work: An organizational process. Sociological Quarterly, 29: 163-178.

Strauss AL. 1993. Continual Permutations of Action. A de Gruyter: New York.

Stuart TE, Sorenson O. 2007. Strategic networks and entrepreneurial ventures. Strategic Entrepreneurship Journal 1: 211-227.

Van de Ven A, Polley D. 1992. Learning while innovating. Organization Science 3: 92-116.

Venkataraman S, Sarasvathy SD, Dew N, Forster WR. 2012. Reflections on the 2010 AMR decade award: Whither the promise? Moving forward with entrepreneurship as a science of the artificial. Academy of Management Review, 37: 21-33.

Ventresca, MJ, Kaghan, WN. 2008. Routines, “going concerns,” and innovation: Towards an evolutionary economic sociology. In M. C. Becker (Ed.), Handbook of Organizational Routines (pp. 52-86). Cheltenham, U.K.: Edward Elgar Publishing. 
Vissa B, Chacar AS. 2009. Leveraging ties: the contingent value of entrepreneurial teams' external advice networks on Indian software venture performance. Strategic Management Journal 30: 1179-1191.

Vissa B. 2011. A matching theory of entrepreneurs' tie formation intentions and initiation of economic exchange. Academy of Management Journal 54: 137-158.

Vissa B. 2012. Agency in action: Entrepreneurs' networking style and initiation of economic exchange. Organization Science, 23: 492-510.

Watson J. 2007. Modeling the relationship between networking and firm performance. Journal of Business Venturing 22: 852-874.

Weick KE. 1979. The Social Psychology of Organizing (Topics in Social Psychology Series). Columbus, OH: McGraw-Hill Humanities.

Weick KE, Sutcliffe KM, Obstfeld D. 2005. Organizing and the process of sensemaking. Organization Science 16: 409-421.

Welter C, Mauer R, Wuebker RJ. 2016. Bridging behavioral models and theoretical concepts: effectuation and bricolage in the opportunity creation framework. Strategic Entrepreneurship Journal, 10: 5-20.

Winter S. 1987. Knowledge and competence as strategic assets. D. J. Teece, ed. The Competitive Challenge: Strategies for Industrial Innovation and Renewal. Ballinger, Cambridge, MA, 159-184

Zollo M, Winter SG. 2002. Deliberate learning and the evolution of dynamic capabilities. Organization Science 13: 339-351. 
FIGURE 1: Process Model of Assembly Perspective of Entrepreneurial Action

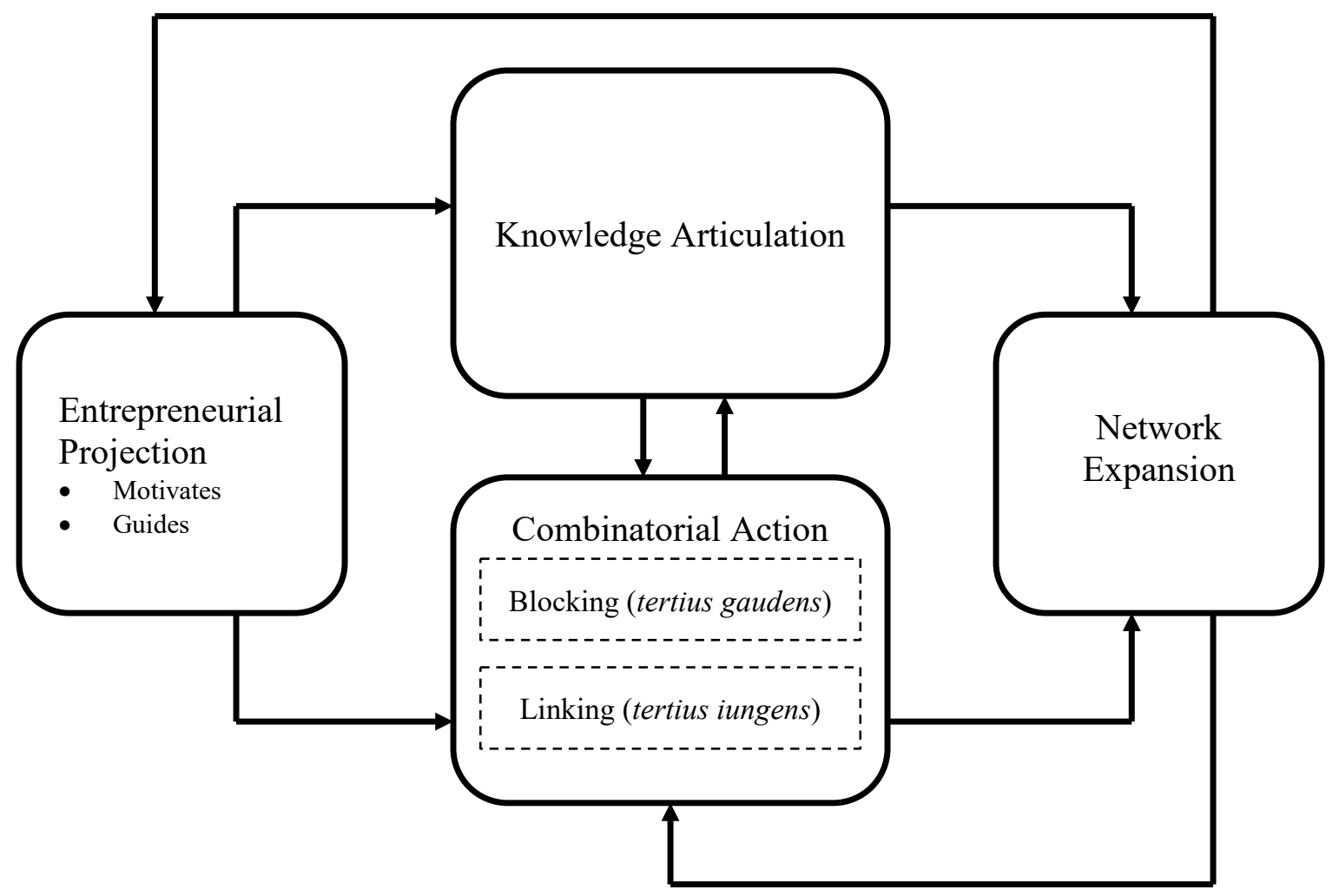


FIGURE 2: Illustration of the Assembly Perspective of Entrepreneurial Action: Walk The Dog Example

TT1

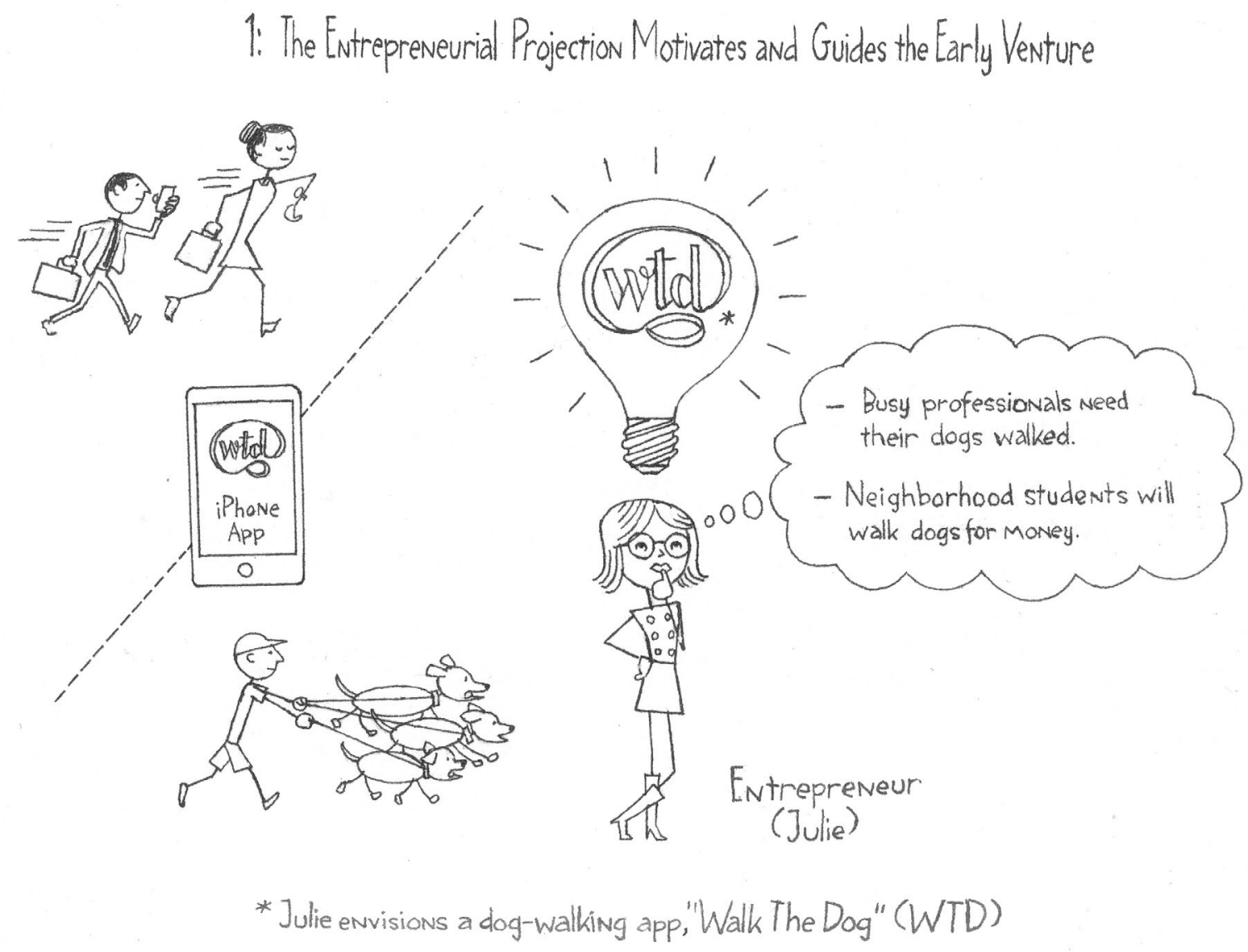




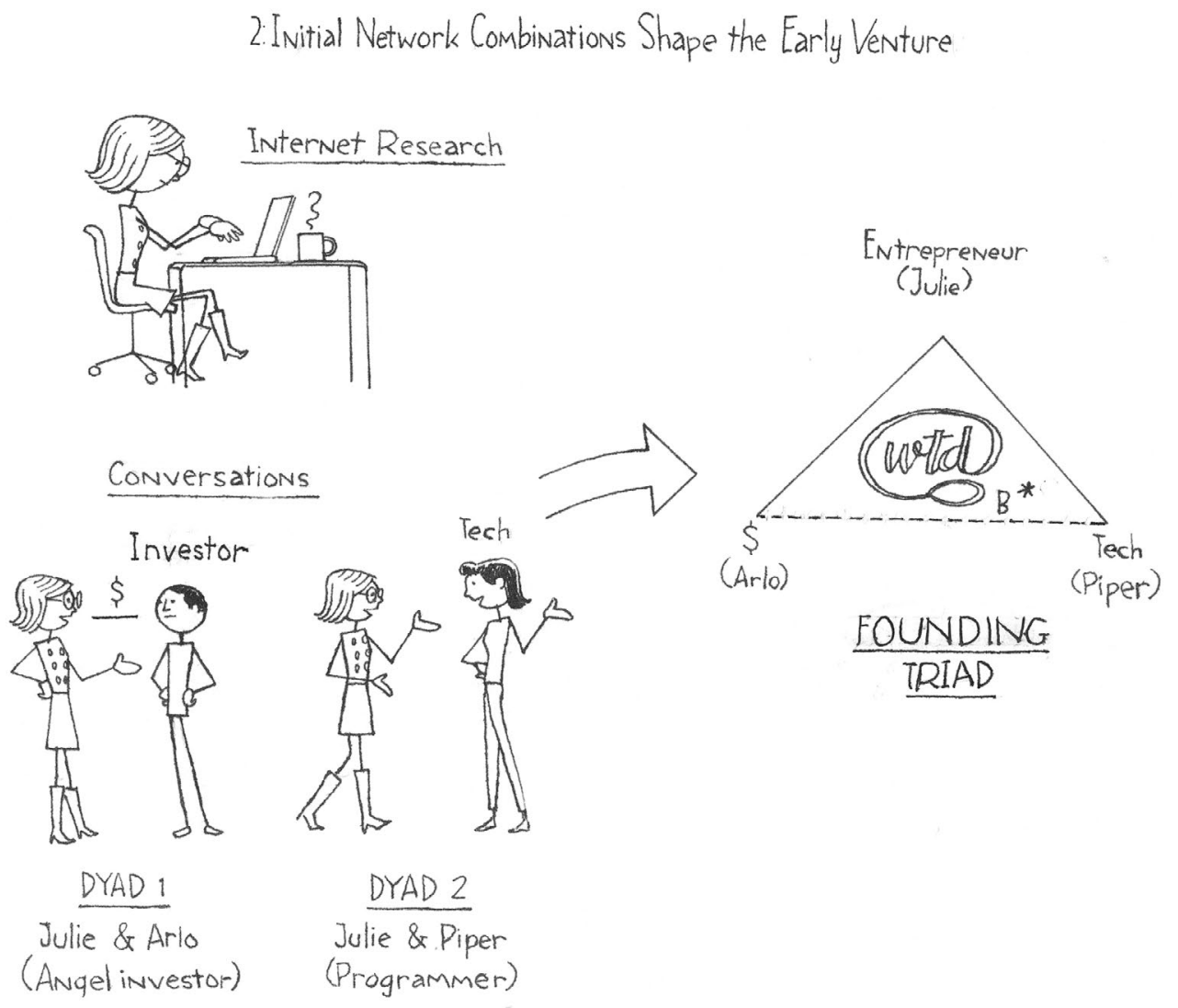

*IN the WTD logo above, the " $B$ "subscript indicates that the entrepreneurial projection has evolved and similarly for C:D, and E subscripts in later variants of WTD. 
3: Core WTD Network Triad Expands Through New Tie Creation

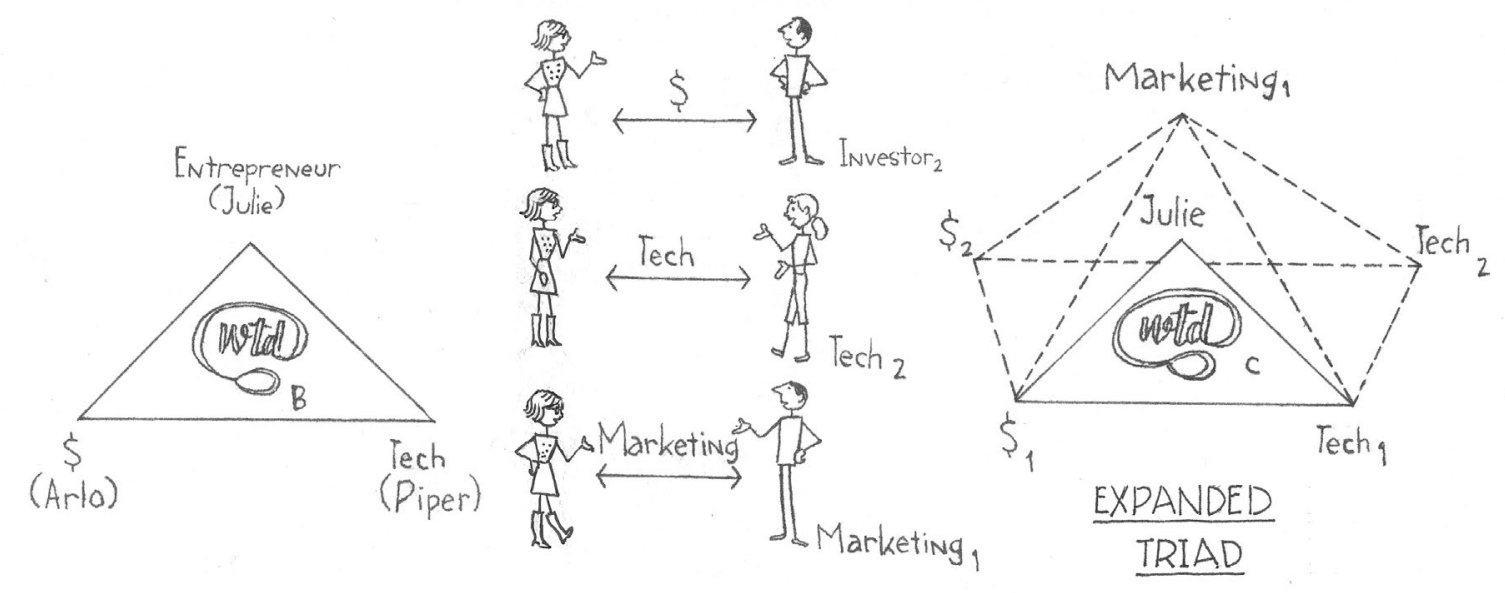


4: Knowledge Articulation: How Entrepreneurs Speak to Diverse Audiences

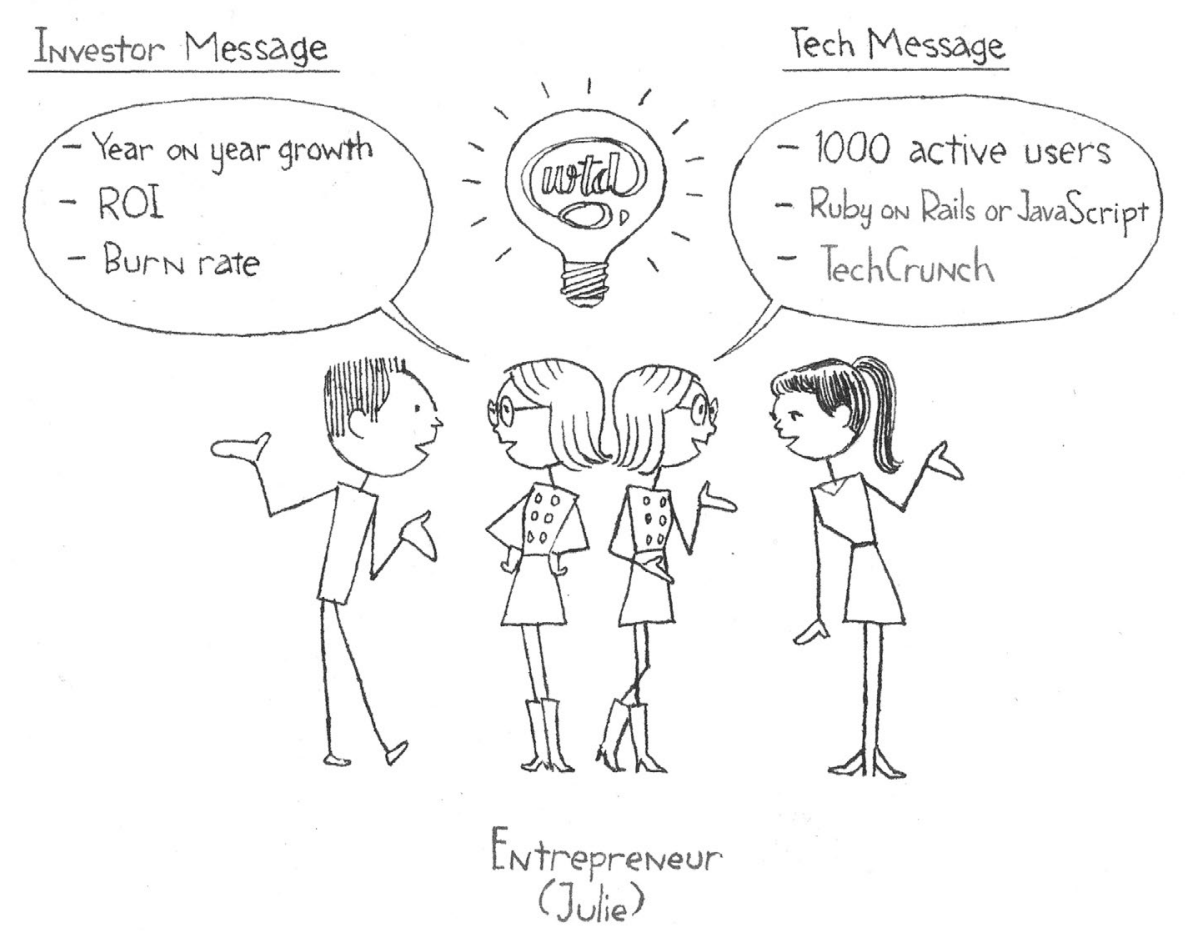


5: How Other Actors Advance WTD Entrepreneurial Trajectory

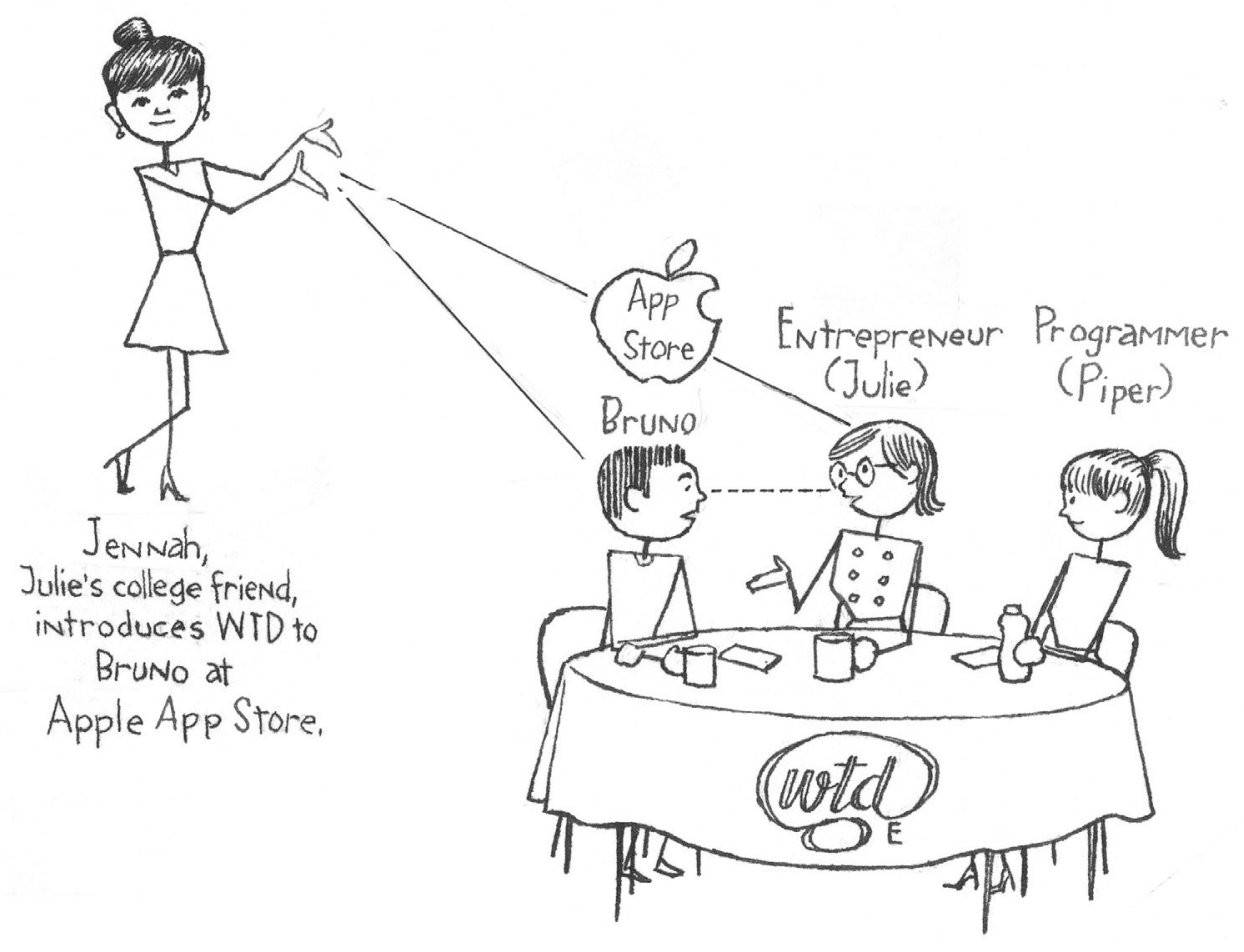


6: How Entrepreneurial Projects Evolve: Roads Not Taken, Postponed, or Redirected

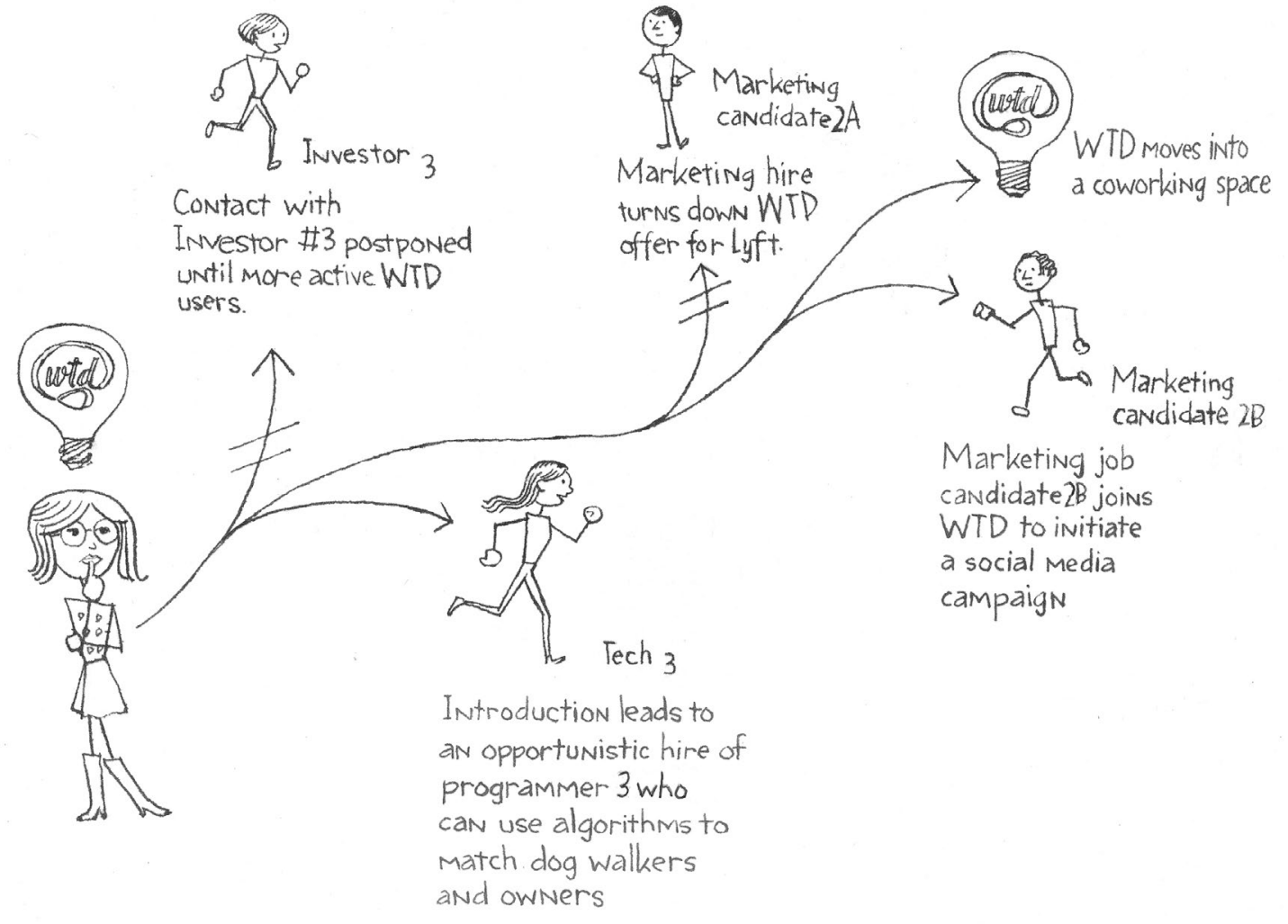


TABLE 1: Components of Assembly Perspective of Entrepreneurial Action

\begin{tabular}{|l|l|l|}
\hline Concept & Description & $\begin{array}{l}\text { Application in } \\
\text { Entrepreneurial Context }\end{array}$ \\
\hline $\begin{array}{l}\text { Entrepreneurial } \\
\text { projection }\end{array}$ & $\begin{array}{l}\text { An evolving vision of an } \\
\text { expected or desired } \\
\text { outcome (Obstfeld, 2012; } \\
\text { Strauss, 1993). }\end{array}$ & $\begin{array}{l}\text { Description or representation of } \\
\text { the opportunity that } \\
\text { entrepreneur discovers or } \\
\text { creates (Alvarez and Barney, } \\
\text { 2007) and a plan to execute on } \\
\text { the opportunity. Motivates and } \\
\text { guides entrepreneurial action } \\
\text { and concept articulation. }\end{array}$ \\
\hline $\begin{array}{l}\text { Knowledge } \\
\text { articulation }\end{array}$ & $\begin{array}{l}\text { "[M]aking knowledge } \\
\text { explicit, useful, or } \\
\text { relevant to the situation } \\
\text { at hand" (Obstfeld, 2012: } \\
\text { 1574; Zollo and Winter, } \\
\text { 2002). }\end{array}$ & $\begin{array}{l}\text { practices (e.g., stories, frames, } \\
\text { analogies, and metaphors) that } \\
\text { provide basis for action (e.g., } \\
\text { Brown and Duguid, 2001; } \\
\text { Lounsbury and Glynn, 2001). }\end{array}$ \\
\hline Combinatorial action & $\begin{array}{l}\text { Proactively joining } \\
\text { people and resources in } \\
\text { new combinations } \\
\text { (Obstfeld, 2005, 2017; } \\
\text { Simmel, 1950). }\end{array}$ & $\begin{array}{l}\text { Meta- and microsocial } \\
\text { combining of concepts, people, } \\
\text { and artifacts to create and } \\
\text { exploit opportunities } \\
\text { (Schumpeter, 1934); making do } \\
\text { with what is on hand in novel } \\
\text { ways (Alvarez and Busenitz, } \\
\text { 2001; Baker and Nelson, 2005). }\end{array}$ \\
\hline Network expansion & $\begin{array}{l}\text { Fostering an increasing } \\
\text { number of linkages and } \\
\text { relationships with and } \\
\text { between a diverse array } \\
\text { of agents. }\end{array}$ & $\begin{array}{l}\text { Increasing the number of agents } \\
\text { with an interest in, } \\
\text { commitment, or contribution to } \\
\text { an entrepreneurial venture over } \\
\text { the startup phase. (Obstfeld, } \\
\text { 2017). }\end{array}$ \\
\hline
\end{tabular}


TABLE 2: Social Action-Based Approaches to Entrepreneurial Projects

\begin{tabular}{|c|c|c|c|c|}
\hline & Effectuation & Bricolage & Creation & Assembly \\
\hline Definition & $\begin{array}{l}\text { A logic of non-predictive control } \\
\text { that takes a set of means as given } \\
\text { and focuses on selecting between } \\
\text { possible effects that can be } \\
\text { created with that set of means. }\end{array}$ & $\begin{array}{l}\text { Making do by applying } \\
\text { combinations of resources } \\
\text { at hand to new problems } \\
\text { and opportunities. }\end{array}$ & $\begin{array}{l}\text { Opportunities are assumed to be } \\
\text { created, endogenously, by the } \\
\text { actions, reactions, and enactment } \\
\text { of entrepreneurs exploring ways } \\
\text { to produce new products or } \\
\text { services }\end{array}$ & $\begin{array}{l}\text { Early entrepreneurial action as network- } \\
\text { based, non-routine, interdependent } \\
\text { combination of people and resources } \\
\text { through which startups are created. }\end{array}$ \\
\hline $\begin{array}{l}\text { Dominant } \\
\text { mechanism(s) }\end{array}$ & $\begin{array}{l}\text { A formative concept consisting of } \\
\text { 1) means or experimentation; } \\
\text { 2) affordable loss; } \\
\text { 3) partnering; and } \\
\text { 4) flexibility. }\end{array}$ & $\begin{array}{l}\text { Combination and } \\
\text { recombination of } \\
\text { constrained and/or non- } \\
\text { obvious resources at hand. }\end{array}$ & $\begin{array}{l}\text { Social construction of } \\
\text { entrepreneurial opportunities; } \\
\text { the agency of individual } \\
\text { entrepreneurs creates } \\
\text { entrepreneurial opportunities. } \\
\text { Applies an evolutionary realist } \\
\text { philosophy. }\end{array}$ & $\begin{array}{l}\text { Tertius iungens (TI): combinatorial } \\
\text { action through which } \\
\text { entrepreneurs/brokers introduce } \\
\text { disconnected individuals (and their } \\
\text { associated resources) or facilitate new } \\
\text { coordination between connected } \\
\text { individuals. TI activity is accompanied } \\
\text { by knowledge articulation (KA), } \\
\text { discursive or representational practices. }\end{array}$ \\
\hline What outcome? & $\begin{array}{l}\text { Ends, goals, outcomes created in } \\
\text { the process that are not } \\
\text { foreseeable at the beginning. }\end{array}$ & $\begin{array}{l}\text { Action often informed by } \\
\text { goals or schema; startups } \\
\text { created "on the fly"; could } \\
\text { be positive or negative; } \\
\text { often involves muddling } \\
\text { through. }\end{array}$ & $\begin{array}{l}\text { The formation and exploitation } \\
\text { opportunities through } \\
\text { entrepreneurial action. }\end{array}$ & $\begin{array}{l}\text { Action motivated and guided by an } \\
\text { entrepreneurial projection that is } \\
\text { "adapted" as action unfolds, evolving } \\
\text { means and ends. }\end{array}$ \\
\hline $\begin{array}{l}\text { Focal "process" } \\
\text { that } \\
\text { characterizes } \\
\text { the approach }\end{array}$ & $\begin{array}{l}\text { Expert reasoning or problem } \\
\text { solving to address highly } \\
\text { unpredictable startups through } \\
\text { choice and negotiated stakeholder } \\
\text { commitments. }\end{array}$ & $\begin{array}{l}\text { Patching, assembly from } \\
\text { resources currently } \\
\text { embedded elsewhere. }\end{array}$ & $\begin{array}{l}\text { An agent centric, path dependent } \\
\text { process in which small } \\
\text { differences in initial decisions } \\
\text { and choices made by } \\
\text { entrepreneurs can lead to large } \\
\text { differences over time. }\end{array}$ & $\begin{array}{l}\text { Entrepreneurial projects: unfolding } \\
\text { trajectories of sequential and parallel TI } \\
\text { combinations of people and the } \\
\text { resources they bear in pursuit of } \\
\text { entrepreneurial opportunities. }\end{array}$ \\
\hline
\end{tabular}




\begin{tabular}{|c|c|c|c|c|}
\hline $\begin{array}{l}\text { Expertise and } \\
\text { social skill }\end{array}$ & $\begin{array}{l}\text { How serial or "expert" } \\
\text { entrepreneurs reason, decide, and } \\
\text { act under uncertainty by avoiding } \\
\text { predetermined markets, goals, and } \\
\text { planning and, instead, identifying } \\
\text { possible causes and choosing } \\
\text { between several possible effects } \\
\text { in a contingent manner. }\end{array}$ & $\begin{array}{l}\text { Actors vary with expertise } \\
\text { with which they engaged in } \\
\text { bricolage. }\end{array}$ & $\begin{array}{l}\text { Individuals may be virtually } \\
\text { indistinguishable, in terms of } \\
\text { their cognitive characteristics, } \\
\text { before the creation process } \\
\text { begins. However, those that take } \\
\text { a more entrepreneurial path over } \\
\text { time may find that certain } \\
\text { cognitive attributes are } \\
\text { positively reinforced which can } \\
\text { create significant differences, ex } \\
\text { post, between individuals who } \\
\text { form and exploit opportunities } \\
\text { and individuals who do not. }\end{array}$ & $\begin{array}{l}\text { Actors vary by social skill or the ability } \\
\text { to induce cooperation or assemble action } \\
\text { through brokerage and KA. } \\
\text { Entrepreneurs skillfully match TI, tertius } \\
\text { gaudens (TG), and conduit brokerage, } \\
\text { and curate among people and resources } \\
\text { to fit the situation at hand. }\end{array}$ \\
\hline $\begin{array}{l}\text { General role of } \\
\text { networks }\end{array}$ & $\begin{array}{l}\text { The entrepreneur's answers to } \\
\text { "who I am," "what I know," and } \\
\text { "who I know" determine the } \\
\text { means at the entrepreneur's } \\
\text { disposal. Dyadic commitments } \\
\text { enable new network ties without } \\
\text { increasing uncertainty. }\end{array}$ & $\begin{array}{l}\text { The bricoleur's existing } \\
\text { network provides a key } \\
\text { resource in the } \\
\text { recombination effort, } \\
\text { constraining or assisting it. } \\
\text { "Social skills and network" } \\
\text { identified as one of the five } \\
\text { elements of counteracting } \\
\text { limitations generating } \\
\text { something from nothing. }\end{array}$ & $\begin{array}{l}\text { Human capital recruited from } \\
\text { pre-existing social networks }\end{array}$ & $\begin{array}{l}\text { Entrepreneurial startup and growth in } \\
\text { unfolding trajectories of social network- } \\
\text { based combination in either open or } \\
\text { closed networks (facilitated by KA). TI } \\
\text { as the master entrepreneurial brokerage } \\
\text { orientation alongside TG and conduit } \\
\text { action orientations. }\end{array}$ \\
\hline $\begin{array}{l}\text { Where does the } \\
\text { approach locate } \\
\text { 'network' } \\
\text { phenomena in } \\
\text { the overall } \\
\text { entrepreneurial } \\
\text { process? }\end{array}$ & $\begin{array}{l}\text { Effectuation process initiated by } \\
\text { entrepreneur reflecting on } \\
\text { questions: "who I am," "what I } \\
\text { know," and "who I know" }\end{array}$ & $\begin{array}{l}\text { Networks are implied to be } \\
\text { relevant throughout the } \\
\text { process. This is not explicit, } \\
\text { but inferred. }\end{array}$ & $\begin{array}{l}\text { Mechanisms for recruiting } \\
\text { human capital for an } \\
\text { entrepreneurial endeavor. Could } \\
\text { be at any stage of the process }\end{array}$ & $\begin{array}{l}\text { The entrepreneur engages existing and } \\
\text { new ties from which combinations of } \\
\text { actors are created that account for the } \\
\text { founding core of the business as well as } \\
\text { pockets of entrepreneurial collaboration } \\
\text { within and outside the emerging } \\
\text { organization. These combinations serve } \\
\text { to help advance and refine the } \\
\text { provisional entrepreneurial projection. }\end{array}$ \\
\hline
\end{tabular}

